Portland State University

PDXScholar

8-1972

\title{
The Nixon "shocks": implications for Japan's foreign policy in the 1970's
}

Richard Douglas Partch

Portland State University

Follow this and additional works at: https://pdxscholar.library.pdx.edu/open_access_etds

Part of the American Politics Commons, International Relations Commons, and the United States History Commons

Let us know how access to this document benefits you.

\section{Recommended Citation}

Partch, Richard Douglas, "The Nixon "shocks": implications for Japan's foreign policy in the 1970's" (1972). Dissertations and Theses. Paper 1574.

https://doi.org/10.15760/etd.1573

This Thesis is brought to you for free and open access. It has been accepted for inclusion in Dissertations and Theses by an authorized administrator of PDXScholar. Please contact us if we can make this document more accessible: pdxscholar@pdx.edu. 
AN ABSTRACT OF THE THESIS OF Richard Douglas Partich for the Haster of Arts in Political Science presented on August 10. 1972.

Title: The Nixon "Shocks": Impllications for Japan's Foreign Policy in the $1970^{\prime}$ 's. APPROVED BY NENBERS OF THE THESIS COMMITTEE:

Dr. Ladis K.D. Kristor, Chaiman Dr. Bernard V. Burka

DF. Brederick L. Schuner

Ihis thesis examines the implications that the Nixon "shocks" may have on Japan's foreign policj. The data used consisted of books, articies, periodicals, government publications and newspapers. Examined were such important factors as: the attitudes of the political parties in Japan on foreign policy questions, the rapia rise of the Japanese economy and the implications this has had or Jepan's relations with other countries, and 
the question of Japan's possible remilitarization, buth in conventional and nuclear terms. In addition, Japan's relations with the other three Great Powers in Asia, (China, the Soviet Union and the United States), are also studied. From about 1945 until the close of the 1960's, Japan's foreign policy had been based on a close relationship with the United States. From about the end of 1970 to the end of 1971, Japan was stung by a series of "shocks" in the course of Americar foreign policy. These included the sudden and last minute announcement of Nixon's visit to China, severe economic measures. the imposition of textile quotas, and the failure of Japan's co-sponsoring of the United Nations motion allowin: Taiwan to keep its membership. The period of 1969 to 1972 is critical to the future alignment of Japan's foreign policy. One conclusion from this re-alimnent is that it is now olear that Japan will no longer serve as the American junior partner in Asia. Japan now shows a new independent attitude in its relations with other countries, quite apart from American desire. Also in 1972 following the Nixon "shocks," both China and the Soviet Union competed against the other to uraw Japan away from its 
American alliance. It is the shift in Japan's foreign policy that this thesis is concemed with. 


\title{
THE NIXON "SHOCKS": IMPIICATIONS FOR JAPAN'S FOREIGN POIICY IN THE 1970'S
}

\author{
by \\ RICHARD DOUGLAS PARTCH
}

A thesis submitted in partial fulfillment of the requirements for the degree of

\author{
NASTER OF ARTS \\ in \\ POIITICAI SOILNCE
}

Portlana Stete University

1972 
TO THE OFFICE OF GRADUATE STUDIES:

The members of the Committee approve the thesis of Richard Douglas Partch presented August 10,1972 .

\author{
Dr. Ladis K.D. Kristof, Chairman \\ Dr. Bernard V. Burke
}

DE. Frederich I. Skbliman

APPROVED:

Dr. Nornan IV. Greene, Fead, Department ot Political Science

Dr.'David T. Clark, Dean of Graduate Studies

August 11,1972 


\section{ACKINOWLEDGMENTS}

I wish to thank the following for their advise, encouragement and help: Dr. Bernard V. Burke, Dr. George A. Carbone, Dr. Ladis K.D. Kristof, Dr. Frank Wunk: Dr. Frederick I. Schuman, and my wife, clare. 


\section{IIST OF TABLES}

TABLE

PAGE

I Political Party Strength in Japan Following

the November 1970 Eleftions .......... 36

II Japan's Trade Computed in Thousands of Millions

of Dollars with China, Taiwan and the

$\mathrm{USSR} \ldots \ldots \ldots \ldots \ldots \ldots \ldots \ldots \ldots \ldots$

II Japan's Export-Import Irade with China Computed

in Thousands of ililions of Dollars .....

IV Some Erojections for Japanese GNP:

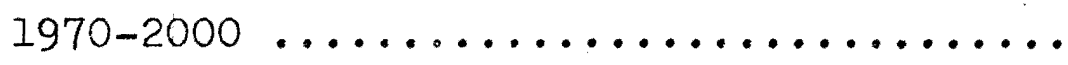

$V$ Japan's Annual Defense Spending: 


\section{TABLE OF CONIENS}

PAGE

ACKNOWLEDGEMENTS

iii

IIST OF TABIES

iv

CHAFTER

I INTRODUCIION $\ldots \ldots \ldots \ldots \ldots \ldots \ldots \ldots$

II POLITICS IN THE POST-WAR ERA .......

III BCONOMIC DEVELOPMENT IN THE POSTWAR PERIOD .................. 41

IV THE QUESTION OF REMILITARIZAIION ....

$\mathrm{V}$ JAPAN-UNITED STATES RELATIONS ....... 84

VI JAPAN'S ROLE IN ASIA ........... 105

VII SINO-JAPANESE RELATIONS .......... 125

VIII JAPAN-SOVIET RELATIONS .......... 142

Conclusion .............. 170

BIBLIOGRAPHY $\ldots \ldots \ldots \ldots \ldots \ldots \ldots \ldots \ldots \ldots \ldots$ 


\section{CHAPTER I}

\section{INTRODUCTION}

The years 1968 and 1969 saw the first important signs of what was soon to become a significant shift in American global foreign policy. Stemming from the unpopularity of American policy in Vietnam, the effects of this shift, as enumerated in the so-called Nixon doctrine of 1969, were to be most dramatically felt in Asia. The concentration of this paper will deal with the reaction that has come from Japan; the country which President Nixon has repeatedly called "America's most important ally in Asia."

The central thesis of the Nixon Doctrine in Asia is that:
The United States will participate in the defense and development of its allies and friends, but that America cannot -- and will not -- conceive all the plans, design all the programs, execute all the decisions and undertake all the defense of the free nations in the world. We will help where it makes a real difference and is consid- ered in our interest. 1

The American goals in Asia are for community of free

${ }^{1}$ Richard Nixon, "U.S. Foreign Policy for the $1970^{\prime} \mathrm{s}$, A New Strategy for Peace: A Report to the Congress," on February 18, 1970. The Department of State Bulletin, Vol. IxII, no. $160 \overline{2}$ (March 9, 1970), p. 276 . 
nations able to go their own way and seek their own destiny with whatever cooperation we can provide -- a community of independent Asian countries developing through mutual cooperation. Ib eertateritics of the Nixon doctrine would contend that as the United states reduced its commitments in Asia, a somewhat proportional reduction in its security would follow.

It is a basic assumption of this paper that as the United states moved to reduce its political, military and economic power in Asia, it concurrently would take two other actions designed to accompany and supplement that move. First, the United states would participate in a general "detente" in Asia (and elsewhere in the world), tending to reduce the "need" of American power. Second, the United States would begin to maneuver Japan into a position of assuming greater political and military responsibility in Asia's future.

In contrast to the above, President Nixon on February 9, 1972, detailed for the United States Congress ${ }^{3}$ exactly what he expected (or hoped) the Nixon

2 "A statement by the President at Bangkok, Thailand, on July 28, 1969," ibid., p. 293.

${ }^{3}$ Richard Nixon, "U.S. Foreign Policy for the 1970's, The Emerging Structure of Peace: A Report to the Congress," on February 9, 1972, The Department of State Bulletin, Vol. LXVI, no. 1707 (March 3, 1972), pp. 313-418. 
doctrine would mean for Japan and the other countries of Asia. In his first point Nixen claimed that, as a result of his meeting with Japan's Prime Minister Eisaku Sato at San Clemente in January of 1972, Japanese-American relations were strengthened. In reality, however, American-Japanese relations following San Clemente were not strengthened. Rather, the meeting by the two heads of state produced little more than only a partial impediment to the continued worsening and weakening of the ties between the two Pacific powers.

A second point made by Nixon in his message to Congress was that the United States would regard a larger Japanese role in the economic and political affairs of Asia not as a substitute for or interference with our role, but as natural, necessary and proper." This statement also fails to be consistent with Asian realities. What in fact the United States was attempting to accomplish in Asia was to push Japan into assuming greater political and military responsibilities. In addition, it seems questionable to assume that the United States would be content with, or would find "natural, necessary and proper," Japan's continued ${ }^{4}$ op. cit., p. 317 
economic expansion in Asia (or in the world). Throughout the Nixon administration (1969 to mid-1972), the official emphasis was on the attempt to stabilize the Japanese economic penetration of, and competition in, American markets. It was during this period that the anguished cries of American businessmen could be heard, oramer for government protection for their respective goods. In short, any increase in Japan's Asian political influence came largely at the expense of the United States.

Given the definite limitations of American power, Nixon's strategy became an attempt to allow for, and even to push, Japan along a more independent route. Japan was believed to be the best alternative to the American decline (of both ability and ambition) in Asia. Second, if Japan assumed part of the financial defense burden of "free" Asia, not only would American military expenses decline, but so in part would Japan's competitive economic resources. Since Japan had previously pressed the advantage of penetrating American markets, why should the U.S. continue footing the defense bills?

One must also question the third point made by . President Nixon in his message to Congress. Therein Nixon stated that the recent American initiative aimed 
at the People's Republic of China was consistent with the continuity of the close U.S.-Japanese relationship. In fact, however, the President knew well in advance that any such American-Chinese rapprochement could be achieved only with the "cost partially being borne in the goodwill of American-Japanese relations. Part of this payment would come "naturally" as a result of the shift in the Asian balance in power. This was largely because any decrease in American-Chinese animosity would somewhat proportionally reduce the very basis of needs in the U.S.-Japanese treaty system. The U.S.-China rapprochement, in this sense, signaled an end to the American Cold War policy of attempting to contain China on all fronts. Indeed, many Japanese would fear that, following the Nixon visit to Peking, they had been left in the Cold War lurch with a government too tired and too inflexible to meet the challenges of a suddenly cold and distant world.

This "unnatural" shock as an element in the U.S.China rapprochement, came with the "methods" used in the initiative. Having informed "America's most important

5In reference to the term "China," it will be meant mainland China (the People's Republic of China).. Any reference to "Nationalist China" will be so specified or referred to as Taiwan.

6 Ibia. 
ally in Asia" only minutes beforehand, Nixon made Japan's Prime Minister Sato appear a fool in the eyes of the Japanese people and the people of the world. By abandoning the policy that the United States and Japan had shared for over a quarter of a century without having either consulted or even informed its Asian ally beforehand, the United States left the government of Japan holding the cold War bag.

A fourth point stressed by President Nixon in his message to Congress found him on solid ground:

Japan is our most important ally in Asia. It is our second greatest trading partner -. Our China and economic initiatives were a shock to the U.S.-Japanese relationship.7

Nixon wandered into a mire however when he speculated that the American-Japanese relationship had,

- . already been overtaken by time and Japan's phenomenal economic growth. The shocks of 1971, therefore, only accelerated an evolution in U.S. -Japanese relations that was in any event, overdue, unavoidable, and in the long run, desirable. 8

That the shocks may have been unavoidable on a cost-gain analysis, limited to their "natural" aspects, is possible. That the shocks were either overdue or desirable has yet to be proven.

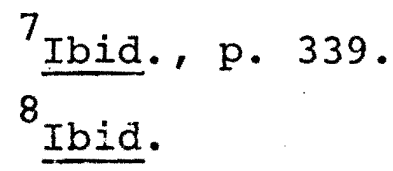


A fifth important point made by President Nixon in his message to the Congress read to the effect that the Nixon administration would enjoy seeing a remilitarized and increased politicized role for Japan in Asia:

Japan has long since acquired responsibility for its own conventional defense. However (the President asks, speaking curiously in the past tense), Japan continued to rely on American nuclear power for strategic security. It was, moreover, prevented by constitutional, political, and psychological factors, and by the attitudes of its Asian neighbors from projecting military power beyond its own borders. Thus the Mutual Security Treaty continued to serve Japan's interests, as well as our own. Still, it was clear that changes would come in our defense relationship as Japan regained its strength and pride. 9

What is unclear is whether, as Japan regained "its strength and pride" and projected its "military power beyond its own borders," this would be done in the longterm interest of the United States.

Added to the inherent political, military and economic problems of Japan's expansion, is the problem of general Asian insecurity. Asia is a region of instability (e.g., Inaochina), fraught with struggles of anti-colonialism, anti-imperialism, nationalism and socialism to name a few. The American withdrawal as indicated in the Nixon doctrine, can only lead to further

$$
{ }^{9} \text { Ibid., p. } 340 .
$$


instability as the remaining powers vie to better their respective positions.

Another important factor of future Asian politics is that, of the world's current five Great Powers, four are committed in strength to the Asia-Pacific region. Only the European Community can be excluded. For the purpose of this paper, a distinction will be made between the terms "Great Power" and "Superpower." of the five Great Powers (i.e., China, the European Community, Japan, the Soviet Union and the United States), only the latter two can be considered superpowers. Japan lacks superpower status since it lacks a credible military, especially nuclear, establishment. Only the two superpowers share global interests and responsibilities that include Asia. The possibility of a future domination by either superpower of the Asian region, even given the' assistance of a third Great Power, would seem remote. This is because the global commitments of the superpowers makes it impossible to concentrate the totality of their power in any one given area. It is also this "global factor" that tends to limit and decrease the superpower's superiority over any third power in a local conflict. The inherent danger for a superpower in overcommitting itself to any one region at the expense of its global responsibilities is clear 
(e.g., the U.S. in Vietnam: 1965 - 1969).

Another factor which diminishes the influence of the superpowers in dealing with either of the other two Asian Great Powers, is that they have their centers of power located at a distance far from Asia. This factor will probably be more important in the case of the United states, and less so in the case of the Soviet Union through the 1970 's. This is because while Soviet influence in the East is generally on the incline (e.g., India), the influence and support of the United States is on the decline. The reduction of American bases in Asia include not only those in Vietnam, but also numerous bases in South Korea, Taiwan, Thailand and Japan. In addition, the assumption of Japanese restrictions of future American rights in the military use of Okinawa (the key base of American Pacific defense), will mean a reduction of American military effectiveness in the region and a probable increase of friction in American-Okinawan (Japanese) relations.

Nevertheless, it must remain clear that the Pacific Ocean acts in the twentieth century less as a barrier than as a conduit between the powers, making for a certain, if often confusing, overlapping of interests. Any change in the Asian balance of power whether positive or negative, opens new opportunities as well 
as dangers to all the nations that share responsibilities in the Pacific area.

Without doubt, one of the region's greatest dangers to peace is the Sino-Soviet dispute. This conflict carries within it a danger to regional peace since it has a high potential for disruption, while simultaneously carrying the greatest of potentials for destruction. It is somewhere within the center-range between these two hostile powers that Japan's foreign policy balances itself. Doth China and the Soviet Union compete for the security that an alliance with Japan would provide. In turn, the Japanese have made their position on a definite comitment to either side purposely unclear. Yet Japan may be forced into some stronger alignment in its policies, given the possibility of a further focusing of acuteness in the Sino-Soviet problem. The current problems between the Soviet Union and China are many of which territorial questions, ideological differences, general deep-seated hatreds, mutual racial contempt, and a variety of age-old rivalries, are only a few. The question of a possible Sino-Soviet reconciliation in the near future is an open-ended one, and is represented by two schools of thought resting at opposite poles. China's current weakness in relation to the USSR (which in 1972 had some 44 army divisions 
stationed on the China border representing over onequarter of the entire Soviet Army and representing 14 more army division than were employed on the border in 1970), 10 would probably indicate a concomitant weak desire to negotiate with the Soviet Union until a significant power shift occurs. In any case, the problem will remain of paramount importance to the future foreign policy of Japan vis-a-vis China, the Soviet Union and the United States.

Although any future combination among Asia's four Great Powers is possible, the tie between Japan and the United States would seem the most stable (assuming that future "Nixon shocks" can be avoided). In contrast, the position of China and the U.S.S.R. seems to be least stable, with both countries having much to gain from any strong affiliation with a third Great Power. In East Asia the most likely and best choice for both countries is an affiliation with Japan.

To a very large degree the future course of Japan's foreign policy will have a tremendous impact upon the balance of power in Asia. While in the past the Japanese could rely on American military protection

10 Taken from a report issued by the International Institute for Strategic Studies in London. See Japan Times (May 3, 1972), p. 4 . 
at a time when they expanded economically, such an open alternative for the future is increasingly doubtful. With the American debacle in Vietnam winding down and the old American policy of quasi-indiscriminate force-application being partialiy transformed into the application of accommodation, the Japanese (and others) are beginning to question the seriousness of American reliance and determination in its commitments to Asia. The Government of Prime Minister Tanaka is aware that any reduction of reliance in the U.S.-Japanese security agreement must mean an increased dependence upon some other Great Power (i.e., China or the Soviet Union), or upon themselves. 
CHAPTER II

POLITICS IN THE POST-WAR ERA

The history of modern democratic Japan emerged from the ashes of World War II. The victors of that war, or more specifically the Americans, grafted a variety of Western values and incentives on post-war Japan. Although the Emperor-system was not to be eliminated as the Soviets vigorously suggested, the personal power and influence of the throne was to be sharply curtailed, and the governmental structure was to be conformed more closely to democratic principles. Japan would be encouraged to develop and strengthen individual liberties, democratic organizations, and, later, a viable economy. In addition, Japan was to be de-militarized, both in terms of the internal leadership structure and in terms of relative international power. These reforms, accompanied by the implementation of others differing in scope but not objectives, were designed to mold Japan in such a way that would make impossible her straying from the path of peace in the future.

The reforms that called for the de-militarization and democratization of Japan also declared that the Japanese people should forever renounce war as a 
sovereign right. The threat or the use of force were to be discarded as a means for Japan to ever settle international disputes, and the Japanese people pledged themselves never to maintain air, sea or land forces or other war potential. All of these stipulations presumed at least two conditions: first, that the policy implemented from above by the Supreme Commander for the Allied Powers (an alien organization), would take hold; and second, that the defense of the Japanese islands would henceforth be adequately preserved by American military power. These assumptions were to be critically tested in the 1970's. With the advent of the Cold War in 1948 the American occupation authorities began to move in a direction that was intended to see a rapid vitalization of the Japanese economy. Within two years, Japanese production had nearly returned to its pre-war levels. Simultaneously, a counterreaction to the re-birth of the economy emerged, both outside and within, the Japanese Communist Party (JCP). The Communists increasingly assumed a role of opposition to the new course that the country was taking. The JCP felt that a rebuilding of the economy would eventually and inevitably lead Japan into a new capitalist war. Ironically enough, it was the occupation's program of political emancipation that 
provided an opportunity for the Communists to become a significant force in Japanese politics. ${ }^{1}$

Peace was signed between the United States and Japan on September 8, 1950. While the United States favored coming to terms with Japan in a policy designed to rebuild the shattered economy, Russia favored punitive action. The Soviet Union felt, as did most other East Asian countries, that Japan should not be allowed to rebuild a strong economic base from which it could again economically and militarily expand.

However, Japan was within the American sphere of control and the strong input of economic assistance that was needed prior to an economic rebirth was both allowed and provided. On the same day that the Japanese-American peace treaty came into effect (April 28, 1952), Japan and the Nationalist Government on Taiwan signed a treaty of peace. At the time, this pact with the Nationalist Government of China: registered its faith that Japan had abandoned its imperialism and became an outpost for the world's defense against communism. Japan recognized Chiang Kai-shek as the sovereign authority in Formosa,

\section{1}

${ }^{1}$ Claude Albert Buss, Asia in the Modern World: A History of China, Japan, South and Southeast Asia (New York: Macmillan, 1964), p. 519. 
the Pescadores, and the territories which might in the future come under his control. Japan was not willing to endorse Chiang's sovereignty over the entire mainland. 2

Throughout and beyond the 1950's and 1960's, Japan was to emerge increasingly as both an economic power in Asia, as well as an economic power in the world. During this period of growth and to the present day, Japan has been ruled continuously by the Liberal Democratic Party (IDP). The platform of this basically conservative party has generally called for peace in the spirit of the United Nations and for a limited rearmament to provide a means of "self-defense." The Liberal Democrats have historically looked unfavorably at atomic or hydrogen weapons, both for use by Japan itself, or by others from Japanese soil (i.e., the United States). The LDP has publicly favored both stronger economic ties with the People's Republic of China, as well as a normalization of political relations with both China and the Soviet Union. Increased trade with both China and the Soviet Union has become a strong element of Japanese economic life.

Since the Second World war the main theme of Japanese politics has been that of the success of the

${ }^{2}$ Ibid., pp. 525-526. 
Liberal Democratic Party in withstanding the challenges by all other parties to their domestic political domination. The Liberal Democrats have ideologically been the bitter foe of left wingism and of the Communists. Especially in the 1950's, but decreasingly in the 1960 's, the strongest party of the socialist movement has been the Japanese Socialist Party (JSP). The Socialists could in the 1950's claim the allegiance of a great mass of the Japanese people. For a variety of reasons, however, the most obvious being the rising affluence of the average Japanese worker, the socialist movement has recently lost much of its support. In the $1960^{\prime} \mathrm{s}$ the greatest support for the JSP came from two groups: the Marxist-oriented students; and the two largest federations of labor unions. ${ }^{3}$ An important problem for the Socialists has been to tie these two divergent groups together in purpose and action. The JSP has also suffered from a variety of other difficulties such as a general lack of funds, failure to gain support from the growing middle class and party factionalism. The cleavages within the ranks of the Socialist party in 1959 were so sharp that a faction of rightists under Nishio Suehiro defected from 3 The Sohyo and the zemo. 
the main party to set up a separate party, the Democratic Socialist Party (DSP): The split of the DSP had come about following a refusal by the right wing of the JSP to accept a statement by the party's assumed leader, Asanuma, made in Peking in 1959, which read to the effect that the Americans, as imperialists, were the common enemy to both Japan and China.

Until the JSP-DSP split, the former had been the only significant left wing party in Japan. The three main ideological tenets of the JSP are: socialism, pacifism and nationalism. The thinking of the Socialist has been generally doctrinaire rather than pragmatic, and this has resulted in a basic antipathy towards capitalist countries, especially the United States. 4 In general, the JSP has opposed American foreign policy in East Asia and its members have wanted to see Japan develop relations with North Korea and North Vietnam. ${ }^{5}$

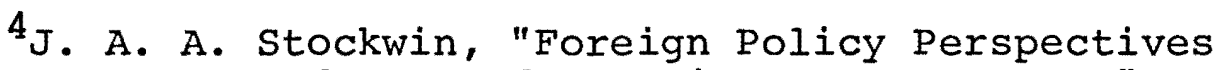
on the Japanese Left: Confrontation or Consensus?" Pacific Affairs, Winter 1969-70, p. 441.

${ }^{5}$ As late as mid-May of 1972 the JSP had reiterated its foreign policy position in the Asia-Pacific region, calling for a neutral zone brought by an establishment of a collective security system. Incorporated within this would be the abrogation of all military alliances between the Asian nations including especially the Great Powers. This would also include the withdrawal of all foreign troops from the Asia-Pacific region with the establishment of a blanket neutrality zone. See The Japan Times, May 15, 1972, p. 2. 
The Socialists have adopted a policy of "positive neutralism" and wish to avoid any military alliances which would commit Japan to another country. The policy of the JSP has been that Japan should stand outside the Western and Communist blocs, but should establish friendly relations with both. In this sense, the JSP has felt for some time that Taiwan is a part of China and that American military forces should be immediately withdrawn. In 1963 the party approved the partial nuclear test-ban treaty, thereby taking a stand approved by the West and the Soviet Union but condemned by China.

A repeated cause for the factionalism that has plagued the Japanese Socialist Party has been the failure of the party's moderates adequately to balance the extremists. There have been a number of splits in addition to the one in 1959 which created the Democratic Socialist Party. For example, as early as 1948 the "Hirano-faction" split from the main Socialist body in January, as did the Nishio faction in July. Both of these factions were of the right wing, and both were reunited to the main body in 1952. A left wing faction also split away from the JSP in July of 1948, forming the Worker-Farmer Party in December. It was not until 1957 at the 13th JSP Convention that the Kuroda faction (i.e., the Worker-Farmer Party), was reunited with the 
main body of Socialists. Another important break within the ranks of the Socialist party came in 1951 when the entire Socialist Party split into the "Left-JSP" and "Right-JSP." A reunification was, however, affected in October of 1955.

In 1965 the Socialists were dominated by the Sasaki faction which set the tone for the party's foreign policy in that decade. "This faction has repeatedly shown itself susceptible to being drawn into the pro-China position favored by members of the extremist 'Heiwa Doshikai' (Peace Friends Association)." 6 The defection of the Communist Party of Japan in 1966 from its former allegiance to Peking coincided with the trend in the Japanese Socialist Party "and was closely related to it."."

An additional complication for Japanese Leftists has been the strong side affect exerted by the centrifugal forces of the Sino-Soviet split. In 1968 the so-called "Yamamoto-Oshiba" group broke from the Sasaki faction (which in 1968 had been the predominant influence within the JSP). The position of the "YamamotoOshiba" group was less doctrinaire than that of the

${ }^{6}$ Stockwin, p. 441 .

7

Ibid. 
Sasaki faction, and wanted to support the policies of the Soviet Union at China's expense. Representing the Maoist line and resting at the opposite end of the party's political spectrum was the Heiwa Doshikai. In both 1969 and 1970 the Heiwa 'Doshikai was increasingly attracting local activists in substantial numbers (which in turn would increase their strength at future party congresses).

Following the Nixon visit to China, it became apparent that the Japanese Socialist Party and the Communist party of the Soviet Union (CPSU) did not share similar views on the issues of either the ChinaUS rapprochement or Japan's moves to normalize JapaneseChinese relations. While recent members of the CPSU visiting in Japan (at JSP invitation) have remarked that the US-China communique, for example, will not ease tensions and was designed only to split the Communist bloc, members of the Japanese Socialist Party have said that the Nixon visit to Peking will help form the necessary conditions for a general "detente" in Asia. For the soviets, the biggest fear in the immediate future is whether Japan might soon normalize relations with both China and North Korea (which would then lead to increased anti-Soviet feelings in Japan.) 
The rise in popularity of the Japanese Communist Party to a prominent place. in Japanese politics is a relatively recent phenomenon. During the 1950's and 1960's the Japanese Communist Party (JCP) exerted less influence than the Socialists, "for the most part because the Communists have often been associated with the Soviet Union (whose earlier opposition to the Emperor-system, for example, has been noted). A general asset for the more recent popularity of the JCP in Japan has been its historical hatred for the policies of the United States.

Since the beginning of Japan's post-war politics the Soviet Union has been looked upon with general disapproval. Several reasons can be identified with the Japanese attitude, the most obvious being the fear that many Japanese have held over the possible ties that may exist between the Communist Parties of Russia and Japan, and the implications that this could have in the political future of Japan. Also, the Japanese remember the Soviet attack on Japan in the last days of the war, and following its quick conclusion, Russian treatment of Japanese prisoners who, when finally repatriated, returned with "lurid tales of forced labor and brain-. washing." 8 A heavy influx of anti-Russian feelings were

$$
{ }^{8} \text { Buss, p. } 630 \text {. }
$$


provided by the repatriations since, according "to Japanese figures, approximately 1,300,000 nationals, including civilians, had been incarcerated by the Russians . . . "9 However, in more recent times this fear has partly subsided, "associated with the current Sino-Soviet split and the relatively independent position taken by the Japanese Communist Party on the matter.

Unlike the Japanese Socialist Party, the Communist Party of Japan did not support the nuclear test ban treaty, and the JCP broke with Moscow in 1963 when the USSR signed the document. The Japanese Communists strongly opposed the treaty on the grounds that it was inflicted with superpower arrogance. The rift between the JCP and Moscow was intensified by what the Japanese Communists regarded as the "meddlesome attempts by Moscow to turn a rebellious faction led by Yoshio Shiga, a longtime party member, into a splinter Communist party subject to Kremlin dicates."10 In 1966, the Japanese Communists refused to send delegates to the 23rd Soviet Congress, and in 1970 declined to

9 Robert D. Warth, Soviet Russia in World Politics (New York: Twayne Publishers, Inc., 1963), . p. 376 .

${ }^{10}$ The New York Times, March 22, 1971, p. 11. 
invite a Soviet delegation to the JCP Congress, even ignoring Moscow's congratulatory message addressed to that meeting.

With the Soviet friendship offensive of 1971 aimed at Japan in general, it appeared that JCP-CPSU relations might improve. On March $2 i, 1971$, the Japanese Communist Party agreed to send a delegation to the 24th Soviet Communist Party Congress, which opened March 30, 1971 in Moscow. The agreement was reached by Tomio Nishizawa, a member of the JCP Presidium, who led a four-man team to Moscow to meet with Soviet Presidium member, Mikhail A. Suslov. But while party relations between the Soviet and Japanese Communists had shown improvements by March of 1972, the Japan-Soviet Friendship Society appeared to be heading for a crisis with its director resigning and most of its other ranking officials threatening to follow suit. The crisis followed a Soviet demand that former dissident members of the Japanese Communist Party be expelled from the Society. The Friendship Society had been important during the 1963-1971 period, serving as a channel for Japanese-Soviet cultural exchanges until the political thaw between the JCP and the CPSU in the spring and Summer of 1971. 
The Japanese Communist Party is the strongest Marxist party in non-Communist Asia and the best organized. Currently its membership numbers over 300,000 and in Japan's 1969 general election, for example, it polled over 3.2 million votes. One observer has noted that the JCP "has been probably the most genuinely pro-Peking of all the Communist parties in the world . . . "1l Its greatest weakness has been that it has been unable to mobilize massive Japanese public support for the Chinese cause.

Diplomacy between Japan and China has been carried out not on official levels, but rather through what the Chinese have called "people's diplomacy." This form of diplomacy exists at all levels other than official ones. It has been largely here that the JCP has been able to act on China's behalf within the Japanese domestic scene.

Although the Japanese Communist Party has been closer to Peking than Moscow since 1963, the JCP's position since 1965 has still been one of basic neutrality. This has been partially due to increased Soviet wooing since 1965, and, also partially from the

${ }^{11}$ Vidya Prakasn Dutt, China's Foreign Policy,

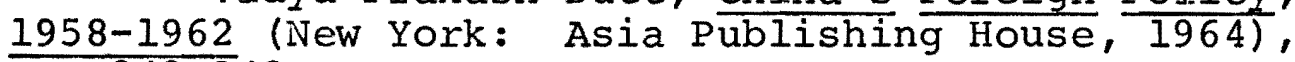
pp. 242-2 43 . 
destruction of the Indonesian PKI (Communist Party), which made the JCP "unquestionably" the most important non-ruling Communist party in Asia. ${ }^{12}$ The JCP had been,

shocked by the results of what was not entirely accurately taken to be Chinese incitement of the PKI, by Chinese objections to 'united action' on Vietnam, by Mao Tse-tung's insistence that the Japanese Communists should seek power by armed struggle rather than parlimentary methods.13

In 1966 the controversy between the Japanese Communist Party and the People's Republic of China was opened for public airing when the Japanese expressed their concern over Mao's "personal backing" against an effort by the JCP to strengthen the Communist position in Vietnam, and by improving sino-Soviet relations. ${ }^{14}$

From the abcve examples, it can be seen that the Japanese Communist Party has not been simply a "camp follower" of either the Communist Party of China or the Communist Party of the Soviet Union. In 1968, for example, the JCP had felt quite free publicly to criticize Moscow severely for the Soviet invasion of

12 Harold C. Hinton, China's Turbulent Quest (London: Macmillan, 1970), p. 225.

${ }^{13}$ Ibid.

${ }^{14}$ Ibid. , p. 133. 
Czechoslovakia, much as it had previously felt free to boycott Mao's preparations for an international conference. The clamor in 1972 within Japan for improved China-Japan relations did not include the JCP. In fact, the Japanese Communists have been, since January of 1972, stepping up their attacks on the Mao Government in China. On the Chinese side, chairman of the JCP Miyamoto, "has been ranked along side American imperialism, Soviet revisionism and the reactionary Sato Cabinet as one of China's four enemies." 15

One observer has commented that the, Chinese leadership appears to feel a mixture of resentment and respect for Japan as a country whose armies withdrew unbeaten from China in 1945 and has staged a phenomenal political and economic recovery from the depths of the period.

In addition, Japan,

would probably be welcome to Peking as a junior political partner if it came under a government sufficiently antiAmerican and far to the left, although not necessarily outright Communist.16

On July 5, 1972, the date of the JCP's 59th anniversary, the party was expected to issue a manifesto of a new political program, ${ }^{17}$ designed to envisage

${ }^{15}$ The Japan Times, April 13, 1972, p. 14. ${ }^{16}$ Hinton, p. 234 .

17 The Japan Times, March 6, 1972, p. 3. 
the creation of a "democratic coalition" government. The proposed coalition would consist mainly of the Japanese Socialists and Communists. In addition, the July manifesto was expected to elucidate on the JCP attitude over the question of the party's non-intervention in the sino-Soviet conflict, the policy of independence, and non-interference by outsiders in its affairs.

Thus, from about 1961, with the creation of the Chairman Nosaka and Secretary General Miyamoto faction and with the adoption of a platform that rejected the policy of seizing power by armed revolution; and in 1963, with the creation and adoption of a policy of non-intervention in the Sino-Soviet conflict and the 1964 explusion of both pro-Soviet and pro-Chinese members from the party; the Japanese Communist Party has since been able to maintain a relative independent position from a dominating influence by Communist parties of either the Soviet Union or of China.

While the Japanese Socialist Party and the Japanese Communist Party both represent the "Old Left," the Komeito Party represents the "New Left." However, the Komeito does not take strong extremist views on Japanese foreign policy and the "content of its official views on foreign policy are close to the traditions of the 
'Old Left.'"18 The Sokka Gakkai, from which the

Komeito broke away, has been described as a:

curious blend of religious revivalism and political activism of undetermined direction which has made rather impressive political gains at the local level, but now seems to be receding as a political force. 19

As Japan's second largest opposition party, the Komeito is both militant and nationalistic and faithfully supported the Chinese admission to the United Nations. ${ }^{20}$ On June 9, 1971, the People's Republic of China invited the Komeito to send a party delegation to Peking. The invitation from China followed by only one day the announcement by the Komeito Party Chairman, Yoshikatsu Tadeiri, that henceforth the Komeito would favor the recognition of Peking as the only government of China. Tadeiri also said that the Komeito would now support the abrogation of the 1952 peace treaty between Japan and the Nationalist government on Taiwan. 21 This

\section{${ }^{18}$ Stockwin, p. 443 .}

${ }^{19}$ John F. Melby, "Great Power Rivalry in East Asia," International Journal (Summer 1971), p. 464.

20 The Japanese Communist Party also supported the Chinese admission to the United Nations, consistent with left wing attitudes, even though recent relations between the JCP and Peking have not always been good. See G.'P. Jan, "The Japanese People and Japan's Policy toward. Communist China," Western Political Quarterly (September 1969), pp. 605-621.

${ }^{21}{ }_{\text {See The New York }}$ Times, June 10, 1971, p. 14. 
action moved the party significantly closer to the policies advocated by the Japanese Socialist Party. The Komeito has historically been on bad terms with the Communist Party of Japan, although it does share certain similar characteristics with the JCP (e.g., both parties gain much of their political support from the urban proletariat).

The Democratic Socialist Party (DSP), which split from the Japanese Socialist Party in 1959 (see pp. 1718), shares the same basic attitude as does the Komeito and the JSP over the question of Japan-China normalization. The Democratic Socialists have also accepted the three Chinese principals to be met prior to China entering into talks with Japan on the normalization question, i.e., that Japan recognize the People's Republic of China as the sole legal government representing China; that Taiwan is a part of China; and, that the Japanese-Ntionalist China treaty be abolished. ${ }^{22}$ Recently, ${ }^{23}$ top-ranking Chinese officials, including Premier Chou En-lai, have praised the new left wing elements in Japan, especially the more extreme groups such as the Rengo Sekigun (United Red Army).

$$
\begin{aligned}
& { }^{22} \text { The Japan Times, April 15, 1972, p. } 14 .
\end{aligned}
$$

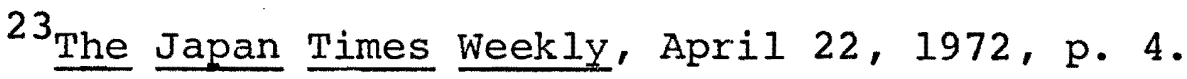


Another extremist faction praised and supported by Peking is the "Fukuda group,". (not related to Foreign Minister Takeo Fukuda), which split from the Japanese Communist Party in 1966.

It would appear that the present generation of young people in Japan are contented with their country's growing role in Asian and world affairs. The new generation of Japanese:

are possibly less discontented with the structure of their society than young people anywhere. The new generation is genuinely internationalist-minded, with an almost desperate urge to be thought cosmopolitan. It is also vigorously proud of being Japanese, at least tolerant of the Emperor system and anxious that Japan play its rightful role as a great power. 24

The students since 1967 have, however, caused certain problems for Japan's political structure. Made conspicuous by their use of violence, the Japanese students have faced the party in power (i.e., the Iiberal Democratic Party), with the same kind of problems not uncommon to advanced and industrial Western nations. For example, the students have attacked the foreign policies of both the Japanese and American governments. Nevertheless, they have also definitely opposed the

${ }^{24}$ Frank Gibney, "The View from Japan," Foreign Affairs, October 1971, p. 102. 
policies of the Japanese Communist Party, which has in turn labeled the students anarchists and Trotskyites. The most powerful party in Japan and the party that has ruled the country throughout the post-war period is the Iiberal Democratic Party (IDP). The IDP is a vast coalition of basically conservative political cliques. The Liberal Democrats are committed to protectionism and trade and rice price support policies, which guarantee the conservative and rural vote. The "China question" of setting forth the conditions for normalization, has been important since before the last decade. In the early 1960's, and as late as 1964, the former Prime Minister Ikeda and his party had been willing to go as far as risking a Taiwanese boycott and $a$,

disruption of trade for the sake of improving trade relations with China and achieving what was virtually 'de facto' recognition. It stopped short of diplomatic recognition under the formula of what was called a 'separation of economics and politics.' 25

However, the coming to power of the sato cabinet brought better relations between Japan and Taiwan at the expense of a significant improvement of Japanese relations with China.

25 F. C. Langdon, "Japanese Liberal Democratic Factional Discord on China Policy," Pacific Affairs, October 1971, p. 404. 
Although the Liberal Democratic Party under Prime Minister Sato has generally been hostile to the People's Republic of China, a substantial body within the IDP has worked for improved relations between China and Japan. In the fall of 1968, the pro-Peking group within the IDP consisted of a combination of about 86 Diet members from both houses which called themselves the Asian-African Problems Study Group. This group of proPeking Dietmen favored the recognition of Peking and its entry into the United Nations. It was felt that if the People's Republic of China gained admission to the United Nations, it would end that country's comparative isolation and would encourage it to cooperate in peaceful ways with the rest of the world.

As of November of 1971, one-third of the entire Liberal Democratic Party strongly supported the position of Taiwan, while a slightly larger group backed Peking. It has been the policy of the pro-Taiwan element that, while Taipei rather than Peking should be recognized as the "real" China, trade with Peking should continue as long as it does not interfere with either Japan-Taiwan relations or with Japan-U.S. relations. However, it has been the pro-Peking group among the LDP that seems to have won over the tacit support of the 
so-called uncommitted members, particularly its younger elements. 26

The group within the Liberal Democratic Party favoring an improvement of Tokyo-Paking relations was led in 1970 by former Prime Minister Aiichiro Fujiyama. On December 9, 1970,

the newly established Dietman's League for the Normalization of Japan-China Relations had its inaugural meeting - . By early 1971, the League claimed 379 members or 51 percent of the Diet... 27

The growing number of groups favoring the normalization of Sino-Japanese relations have become increasingly frustrated and militant, especially in 1972, since their policy of recognition has, as of yet, not been supported by the ruling leadership of the Liberal Democratic Party. The more powerful of these diverse groups and organizations, to name only a few, include: the Japan International Trade Promotion Association, the Japan Dietman's League for the Promotion of China-Japan Trade,

${ }^{26}$ Koji Nakamura, "Changing Power Balance," Far East Economic Review, November 27, 1971, p. 8 . 27 William Saywell, "Japan's Role in the Pacific and China's Response," International Journal, Summer 1971 , p. 517. 
the Japan-China Friendship Association, the Japan

National Peace Committee, the Japan Red Cross Society, the Japan Science Conference, and the Asian News Service. 28

The domestic rewards for Prime Minister Sato's policies, including the one that governed China relations, reached its height of public approval in 1969.

In late December, 1969, Sato's ruling LDP won a smashing electoral victory, gaining a stronger grip on the Diet - . while the opposition Socialists -. lost 50 seats.29

By November of 1970 , the political climate in Japan had changed (see Table I).

By October of 1971, in a national opinion poll, only 23 percent of the Japanese people supported the Sato government. 30

Part of the reason for the sudden collapse of Sato's domestic political support is that, Japan's current leadership is hardly in-
spiring. The Sato government has steadily
played cautious international politics, con-
tent to follow the U.S. lead in most matters,
28 For a more complete list, see Jan, p. 612 .
29 Walter LaFeber, "China and Japan: Different Beds,
ent Dreams," Current History, (September 1970), Different Dreams," Current History, (September 1970),
p. 144. ${ }^{30}$ Nakamura, p. 8 . 
TABLE I

\section{POLITICAL PARTY STRENGTH IN JAPAN FOLLOWING THE NOVEMBER 1970 \\ ELECTIONS 31}

\begin{tabular}{lcc}
\hline \hline & Lower House & Upper House \\
\hline LDP & 303 & 139 \\
JSP & 91 & 63 \\
Komeito & 47 & 24 \\
DSP & 32 & 9 \\
JCP & 14 & 7 \\
Others & 3 & 6 \\
& & \\
\hline
\end{tabular}

conservative to a fault. The Socialists, the major opposition party, are not only committed to a kind of high-buttoned shoe Marxism which flies in the face of Japan's economic reality but their Mao first, anti-imperialist foreign policy embarrasses the other opposition parties, including the Communists. 32

Regarding China, the Liberal Democratic Party's basic attitude had been until the Nixon trip to Peking, without initiative, content to faithfully follow the direction set by the U.S. since early in the cold war.

To a great extent, however, the collapse of Sato's popularity has come with the embarrassment of the sudden and unsuspected "Nixon-China" shock. It has also meant

\footnotetext{
31"China's New Diplomacy: A Symposium II," Problems of Communism, XXII (January-February, 1972), p. 75 .

32 Gibney, p. 102.
} 
for Japan a casting away, to a yet undetermined extent, from the Japanese-American alliance and the close ties of cooperation. In late 1971 it was reported that the,

left-Socialists and most other nonCommunist opposition groups-- which together drew 41.5 percent of the vote compared to 44.6 percent for the Liberal Democrats in the June Upper House elections-- not only favor accommodation with Peking but would terminate the American alliance and United States' base rights in Japan and Okinawa. 33

By October of 1971, following the ouster of Nationalist China from the United Nations and the total failure of Sato's support for the unpopular U.S. position, outside of Taiwan and possibly the United States,

the impact of the UN decision appeared to be felt hardest in Japan, America's major ally in East Asia and Communist China's chief rival for influence in the region. 34

Following the failure of Sato's pro-U.S. and pro-Taiwan position, the Prime Minister was subjected to a bitter attack by the four opposition parties, by labor unions, many businessmen, and a significant portion of his own party for having sided with the United States and the losing side. One Japanese official said: "For the first

33 The New York Times, August 9, 1971, p. 28.

34 The New York Times, October 27, 1971, p. 1. 
time since World War II we are losers," and the "Sato government is responsible for our siding with the losers." 35

Following the sato policy failure, the call for his ouster grew louder from the opposition parties and from many private citizens. The Japanese Socialist Party, for example, issued a statement which declared that the,

deceptive assertion that the United States and Japan have maintained for 20 post-war years, that the Taiwan regime was the only legitimate government of China, has collapsed by the action taken in the United Nations, and the containment policy directed at China has broken down. This represents the complete defeat of Japanese diplomacy concluded by the sato government . . the Sato government should resign immediately to take responsibility for its failure. 36

Nevertheless, on the same day that the JSP statement was issued, the sato government withstood two attacks by the four opposition parties in the Lower House by votes of 274 to 169 and 280 to 171. The following day the Sato government also survived an attack in the Upper House by a vote of 132 to 106 .

Sato's Foreign Minister, Takeo Fukuda, was his choice to replace him as Prime Minister. Sato's

35 Ibid.

${ }^{36}$ Ibid. 
retirement had technically meant he was giving up only his party post as President. If Fukuda had replaced him as Prime Minister, it would have meant that sato could have retained some influence in the government. The choice of Kakuei Tanaka by the majority of the Liberal Democratic Party to replace Sato meant a rejection of the latter's cautious politics. In addition, Sato's seal of approval on Fukuda for the post of Prime Minister probably turned out to be more of a liability than an asset.

The choice of Tanaka was not inconsistent with the current trend in Japanese politics today. As in many Western countries, the leftward political trend in Japan is representative of the changing economic and social conditions and values. In part, the longevity of power by the ruling IDP has come with the failure of the left to create an ideological umbrella in which all the opposition parties could gather under. This failure is also indicative of the lack of success thus far by the opposition parties to draw the necessary substance for political power from the various factional groups, citizens, and interests who often give only begrudging support to the Iiberal Democrats.

With oppositional disunity being a major problem neither the Democratic Socialist Party nor the Komeito 
favor joining with any left wing elements of the other parties (e.g., the DSP will join with the right wing of the JSP but not with the Communists, which the JSP wants included). 37 Two power coalitions as alternatives to the IDP are currently in the process of developing and growing in strength: first, the JCP and the left wing of the JSP; and second, a coalition of the Komeito and the DSP. In 1972, the three biggest cities in Japan were ruled by members of the JSP left wing or by Communist-backed candidates. One observation has gone as far to note that at Japan's current rate of urbanization, the Japanese Communist Party could rule the country by 1979.38

${ }^{37}$ Far East Economic Review, March 4, 1972, p. 32 . ${ }^{38}$ Ibid. 


\section{CHAPTER III}

ECONOMIC DEVELOPMENT IN THE

POST-WAR PERIOD

Japan has since the Sino-S"oviet split found itself searching for a new image and status in Asia. The American withdrawal and reduction of power finds Japan moving hesitantly forward to fill some portion of the newly created vacuum. During the 1970's, Japan will face a number of important questions including: (1) the northern territories issue; (2) the Sino-Soviet conflict: (3) the Japan-China normalization issue: (4) the problem from limited American withdrawal in Asia; and, (5) the rapid rise of the Japanese economy.

Japan has long since become an economic world power. In Asia, Japan is now the dominant economic force. This power, however, has not come without arousing a great deal of fear and resentment. The Japanese abroad are often referred to as the "Yellow Yankees" or "Ugly Japanese." At home it "has already become fashionable . . to speak of 'Japan's special responsibility,' and 'special interests' in this area, 'the single destiny of the Asians,' and the like."1

$1_{R}$. Hutching, "Soviet Defense Spending and Soviet External Relations," International Affairs (July 1971), p. 58 . 
Although few would fail to concede the Japanese their rapid economic growth and strong influence in Asia, not all would go so far to say that the,

expansion of Japanese monopoly capital in Southeast Asia is equally aimed at gaining economic benefits and political advantages. Tokyo is lined by mirages of a recreated 'co-prosperity sphere . . . 12

To a large degree, it is a matter of perspective whether one chooses to see Japan's growth as sinister or positive in nature. In the defense of that country's policies, one could observe that "Japan has been called upon to play an increasingly important role in the global attempt to realize a peaceful and prosperous world community." 3 During the decade of the 1960's, the emphasis on Japan's trade was increasingly placed in the direction of the developed and Communist bloc countries. In 1960, 47.6 percent of Japan's trade went to developed countries and 50.6 percent to less developed, while only 1.8 percent went to Communist countries. 4 By 1969 , those

2 Ibid. , p. 43 .

3 Kei Wakaizumi, "Japan and Southeast Asia in the 1970 's," Current History (April 1971), p. 200.

${ }^{4}$ Hakusho Tsusho, "Japan Ministry of International Trade and Industry White Paper on International "rade" (1970), p. 140. See Koji Taira, "Japan's Economic Relations with Asia," Current History. (April 1971), p. 228 . 
figures had changed in that, 52.1 percent of Japan's trade now went to developed countries, while only 43.1 percent went to less developed. The amount going to Communist countries in 1969 had also risen to 4.8 percent. More recently, the Japanese business community has been moving to strengthen economic ties with East Europe. ${ }^{5}$ For the purpose of promoting increased trade, Japan has been attempting to establish bilateral private economic committees with the countries of Czechoslovakia, Poland, Rumania, and Yugoslavia. Such committees already exist between Japan and East Germany, Hungary and Bulgaria.

\section{TABLE II}

JAPAN'S TRADE COMPUTED IN THOUSANDS OF MILLIONS OF DOLLARS WITH CHINA, TAIWAN AND THE USSR6

\begin{tabular}{l|r|r|l|l|l|l|l}
\hline & \multicolumn{1}{|c|}{1961} & \multicolumn{1}{|c|}{1962} & 1963 & 1964 & 1965 & 1966 & 1967 \\
\hline Japàn-USSR & 210.3 & 296.6 & 320.0 & 408.5 & 408.5 & 514.3 & 611.5 \\
Japan-China & 47.5 & 85.5 & 137.0 & 310.4 & 469.7 & 621.0 & 557.7 \\
Japan-Ta1wan & 164.0 & 179.9 & 229.7 & 278.7 & 375.2 & 402.7 & 465.2 \\
\hline
\end{tabular}

5 The Japan Times Weekly, March 13, 1972, p. 4. ${ }^{6}$ Chae-Jin Lee, "The Politics of Sino-Japanese Trade Relations, 1963-1968," Pacific Affairs (Summer 1969), p. 131. 
The breakdown of Japan's trade with three of its major partners illuminates several factors. One factor is that the greatest increase of trade during this period occurred between Japan and China. Moreover, while trade between Japan and both the USSR and Taiwan experienced a steady annual increase, trade between Japan and China in 1967 showed a marked drop. This sudden decrease in trade volume can be explained in part, not exclusively in terms of Japan-China relations, but also in terms of the general Chinese withdrawal throughout the world, due to the Cultural Revolution. It has always been the Chinese practice to exert influence on Japanese domestic politics through its commercial contacts. Japan's trade with China from 1967 to 1971 indicates two further factors.

TABLE III

JAPAN'S EXPORT-IMPORT TRADE WITH CHINA COMPUTED IN THOUSANDS ${ }_{\text {DOLIAARS }}{ }^{\text {OF MILLIONS OF }}$

\begin{tabular}{|c|c|c|c|c|c|}
\hline & 1967 & 1968 & 1969 & 1970 & 1971 \\
\hline Japanese expc & 288.3 & 325.4 & 390.8 & 568.9 & 577.6 \\
\hline Japanese imports & 269.4 & 224.2 & 234.5 & 253.8 & 322.2 \\
\hline $\begin{array}{l}\text { Total Japan/ } \\
\text { China Trade }\end{array}$ & 557.7 & 549.6 & 625.3 & 822.7 & 399. \\
\hline
\end{tabular}

7 Toshitaro Fukushima, "Politics Not in Command," Far Eastern Economic Review, March 4, 1972 , p. 44. 
First, beginning in late 1968 or early 1969,

Japanese-Chinese trade showed a marked increase; and second, throughout this period, Japanese exports to China have greatly exceeded imports. Japan's exports to Taiwan have also usually exceeded imports. In the year 1969 , for example, out of a total of $\$ 700$ million in trade, $\$ 517$ million consisted of Japanese exports to Taiwan.

Without question the most important problem that has arisen from the excess ratio of Japanese exports over imports has not come in the case with Taiwan, but has occurred with the United States. On March 1, 1972, United States Secretary of the Treasury, John B. Connally, predicted that the U.S. would incur a $\$ 1,800$ million to $\$ 2,000$ million deficit with Japan in 1972 despite the new realignment of currencies brought about in the previous year. In 1971, the total U.S. deficit had reached a record $\$ 3,206$ million, $^{8}$ and had brought

8 From January through May of 1972, the United States had already incurred the greatest deficit for any given year in its history. With seven months still remaining in the year, the deficit was still rising beyond the $\$ 3200$ level (although the positive effects from President Nixon's economic policies would probably not be felt until later in the year). 
about President Nixon's new economic policy. On December 18, 1971, the American initiative known in Japan as the "dollar-shock" brought about a revaluation of the Japanese yen which reportedly cost Japan's businesses and industrial interests in the first four months of 1972 over four billion dollars. 9

Since the yen "upvaluation," Japanese industries have been diversifying, no longer depending heavily on America as an export market. 10 For example, Japanese exports to the United States for the month of March, 1972 , was $\$ 817,680,000$, up 19.4 percent from a year ago. But for the same month, Japanese exports to West Europe was $\$ 447,620,000$, up 25 percent from a year ago, while Japanese exports to the Communist countries for March totaled $\$ 152,400,000$, up 31.5 percent from a year ago. Nevertheless, the United States was expected to continue to press for further liberalizations of trade and capital transactions with Japan. 11 The Nixon revaluation, or "dollar-shock," helped to further the Japanese recession. Japan's Gross.

${ }^{9}$ The Japan Times Weekly, April 15, 1972, p. 8. ${ }^{10}$ Ibid., April 22, 1972, p. 9.

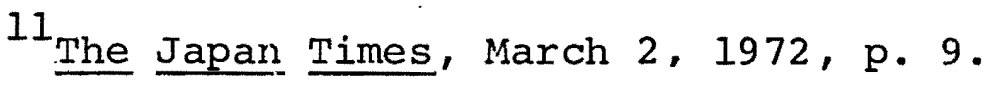


National Product suffered a major drop in 1971 for the first time since the recession year of 1965. It was reported in April of 1972 that the "Japanese economy is still in trouble as it enters the fiscal year 1972 . The recession is now in its twentieth month . . ."12 The Gross National Product for 1971 was up only 6.1 percent in real terms. The annual growth rate since 1966 has normally ranged from 10 percent to 14 percent. The official "low" prediction for fiscal year 1971 ending on March 31, 1972, was 4.3 percent, the lowest since 1955.13

The major economic problem between America and Japan has been that Japanese exports to the United States have exceeded imports. This problem has created a surplus of American dollar reserves in Japan. For Japan, the question has been how to increase imports without worsening the 'domestic recession. Inactivity at arriving at some conclusion by the Japanese could wreck the delicate balance of the international monetary system. The problem for the United States has been, and is, how to be more competitive in the world market.

\footnotetext{
12 The Japan Times Weekly, April 15, 1972, p. 4. ${ }^{13}$ The Japan Times, March 2, 1972, p. 1.
} 
Japanese foreign reserves with all foreign countries were, by the end of 1971, figured to be $\$ 15,235$ million. By the end of 1972, that figure could reach a total of over $\$ 20,000$ million, and by 1973 over $\$ 30,000$ million. ${ }^{14}$ In comparison, the United States in 1971 held only $\$ 12,000$ million in foreign reserves. Also by comparison, Japan's overall balance of payments during fiscal 1971 recorded a surplus of $\$ 8,043$ million, over four times that of 1970. Japan today holds more foreign currency reserves than any other country in the world except West Germany. The build-up of foreign reserves in Japan will probably make Tokyo the eventual major money market in Asia.

Japan has become the Soviet Union's najor trading partner outside of the Soviet bloc and Japan is now the major worldwide trading partner of the People's Republic of China. At the same time, Japan's major trading partner is still the United States, which absorbs about 30 percent of all Japanese exports. During the 1960's and 1970's, Japan also developed a strong economic relationship with the smaller countries of Asia. At the Asian Development Conference held in Jakarta in April of 1970, Japanese Foreign Minister Kiichi Aichi revealed that

${ }^{14}$ Far Eastern Economic Review, March 4, 1972, p. 33. 
Japan was prepared to aid the smaller countries in Asia by offering them 1 percent of Japan's total income (i.e., \$1.8 billion). ${ }^{15}$

Also during the 1960's, Japan's Gross National Product more than tripled and with the real annual economic growth rate averaging approximately 12 percent, Japan moved past both West Germany and the People's Republic of China to become the world's third most productive state. For the future, new markets as well as new discoveries of natural resources will be needed, and Japan has already assumed a major role in both trade and investment in all of Asia including both Taiwan ${ }^{16}$ and South Korea. By the mid-1970's, assuming Japan sustains its current economic pace and that the rest of Asia continues to grow at its present rate, Japan's Gross National Product will virtually equal that of all other Asian nations combined. ${ }^{17}$ During 1969, Japan

${ }^{15}$ Myung-Kun Yiu, "The Prospects of Japan's Rearmament," Current History (April 1971), p. 234.

${ }^{16}$ In March of 1971, Japan's investment in Taiwan totaled $\$ 634$ million. See The New York Times, March 3, 1971 , p. 14.

${ }^{17}$ Wakaizumi, p. 200 . 
led the world in trade expansion growing at a rate of 23.7 percent, compared to the, world average of 13.5 percent. At Japan's normal expansion rate of about 12 percent (assuming that the "Nixon dollar-shock" recession wears off soon), ${ }^{18}$ the Japanese could overtake the economy of the Soviet Union by the late 1970's.

H. Kitamura attempted to explain Japan's growth rate by theorizing that a high rate of growth in manufacturing products causes a rapid growth of both productivity and employment in the secondary and tertiary sectors. ${ }^{19}$ However, once the investment sector is fully developed and once a large share of the world trade in investment goods has been acquired, the growth rate is bound to recede. Kitamura predicts that he, would grant that Japan still has the possibility of economic growth at a rate of over 10 percent a year for some time to come (but, he adds), I am . . inclined to predict that the time will come relatively soon when the single-minded pursuit of economic

${ }^{18}$ According to a leading private economic research institute in Japan (The Nornura Research Institute of Technology and Economics of Tokyo), the current recession should soon end. By 1974, the Japanese economy should again enter into another boom period at a growth rate of 11.3 percent, lasting until about 1976. See The Japan Times, March 23, 1972, p. 14.

${ }^{19} \mathrm{H}$. Kitamura, "Japan's Economic Growth and its International Implications," World Today (May 1971), pp. 195-202. 
growth in the purely quantitative sense has to be modified. 20

From about 1955 on, Japan experienced a national economic boom which was centered in heavy industry, chemicals, and, to a lesser extent, the technological industries, especially electronics. Following the American "hints" leveled at Japan to begin directing the building of military hardward, certain Japanese industrialists and businessmen revolted against the production of military goods and rather toward the production of quality items, shifting away from the massive export market and towards the Japanese consumer market. However, if the Japanese economy is to switch from other forms to luxury consumer goods, it will have to provide for its workers the increased wages necessary to buy them. In 1971, the real gain in Japanese worker's incomes rose by only 3.9 percent, the smallest increase in six years. 21

The switch from quantity to quality, and from heavy and chemical industries of mass production to highly sophisticated and knowledgeable industries, is not the only economic problem Japan faces. Other questions of social reform that the economy of Japan must answer

$$
\begin{aligned}
& { }^{20} \text { Ibid., p. } 198 .
\end{aligned}
$$

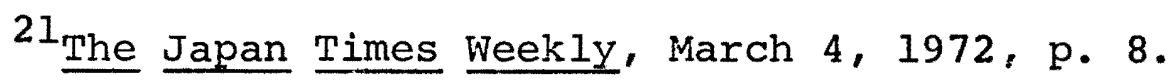


are: environmental pollution, structural reform of the educational system, liberalization of imports, fulfilling the expanding needs for raw materials, energy resources, and foreign markets; and, a settlement of the labor shortage, rice surplus, and judicial and party political struggles. In the past, Japan has been one of the world's worse offenders of water, air and land pollution.

The worsening pollution of air and water has resulted from exclusive concentration on the immediate, quantitative expansion of industry, coupled with disreqard for the consequences of industrial wastes and other poliutants on the environment. 22

The expanding needs for economic resources pose strategic problems for Japan's policy makers. For example, Japan is the world's greatest importer of natural resources. Since 1965 the Japanese demand for resources, in a world where the total supply is limited, has risen from 10 percent to 20 percent each year. 23 In $1970,44.3$ percent of all Japanese imports were in the form of raw materials. From 55 percent to 75 percent of all copper, lead, and zinc, as well as all aluminum, nickel, petroleum and uranium had to be

22 Far Eastern Economic Review, March 4, 1972, p: 50. ${ }^{23}$ See The Japan Times Weekly, April 22, 1972, p. 12. 
imported. Japan currently depends on oil for 70 percent of her energy needs (by contrast, the U.S. depends on oil only 40 percent). Prime Minister Sato has suggested that Japan's greatest problem for the next 30 years will be fuel supply. 24

Currently Japan has enough oil stockpiled to last only 45 days without resupply. The Japanese search for petroleum has nearly reached the point of desperation. One suggested possible solution for this problem calls for a direct oil agreement with Iran. The effectiveness of this suggestion is limited in that it does not answer the age-old problem of supply, given international hostilities. Japan has also probed, as a second possibility, the gaining of access to Alaskan oil. The consortium formed by the several oil companies to build the trans-Alaska pipeline, however, has denied that any oil from the North Slope will go to Japan. 25 An encouraging report was that an underseas oil field containing a quantity of low sulfur oil had been discovered along the continental shelf in the Sea of Japan. 26

\footnotetext{
24 The New York Times, April 9, 1972, p. 1, Section III.

25 The Japan Times, May 13,1972, p. 4.

26 The Japan Times Weekly, March 4, 1972, p. 9.
} 
Another possible solution may come from the 59 nuclear plants which are expected to be functioning by the year 1985.27 By 1990, over half of Japan's power needs could be met by nuclear power; by the year 2000 , 71 percent. However, this does not necessarily answer the question of the source of raw materials, i.e., these suggestions are limited only to altering the type of material needed (from petroleum to uranium).

It has been suggested that by 1975 Japan's economy may become larger than the combined gross national product of West Germany and the United Kingdom combined. 28 Kitamura has also predicted that, while Japan's foreign investment balance at the end of 1968 was slightly less than $\$ 2,000$ million, indications are that by 1975 Japanese foreign investments will rise to a level of $\$ 20,000$ million. By 1980 , that figure may rise again to the new height of $\$ 100,000$ million. The fact that Japan started at such a low economic point some twenty-five years ago and has risen so far growing so fast, will cause in the future severe economic adjustments throughout the entire world.

\footnotetext{
27 Far Eastern Economic Review, March 18, 1972, ${ }^{28}$ Kitamura, p. 199.
} 
Herman $\mathrm{Kahn}^{29}$ has predicted that by the year 2001, Japan will be the world's pre-eminent economic porer. He has also predicted that by 1990 Japan's per capita income will have surpassed that of the United States.

\section{TABLE IV}

SOME PROJECTIONS FOR JAPANESE GNP : $1970-2000^{30}$

\begin{tabular}{lrrrr}
\hline & Low & Official & Medium & High \\
\hline 1970 & 200 & 200 & 200 & 200 \\
1975 & 300 & 330 & 350 & 400 \\
1980 & 450 & 550 & 600 & 750 \\
1985 & 600 & 825 & 1000 & 1300 \\
2000 & 1500 & 2000 & 3000 & 4500 \\
& & & & \\
\hline
\end{tabular}

Given in billions of 1970 dollars.

At any rate, the future of Japan's economic expansion will be significant. In addition, some proportional increase in Japanese political influence can also be expected. The possibilities of an expanded Japanese military role in Asia is the subject for the

29 Herman Kahn, The Emerging Japanese Superstate: Challenge and Response (Englewood Cliffs: PrenticeHall, 1970).

30 Taken from Herman Kahn and Max Singer, "Japan and Pacific Asia," Asian Survey, Vol. XI, No. 4 (April 1971), p. 409 . 
following chapter. The,

challenge to Japan of the new international situation is to search for policies and behavior compatible with her position as a responsible member of the international community, and the community of industrially advanced countries in particular. The extent to which Japan may cooperate in the task of expanding world trade and investment in a stable manner will depend critically on whether the outside world j.s prepared to treat her as an equal partner, respecting her own legitimate interests. 31

At the same time it is possible that,

Japan once again may adapt herself too well to the power play of new imperialism as an efficient subcontractor of the worldwide socio-economic and political engineering initiated and managed by the West. Japan's diplomatic immaturity is well-known . . Japan looks down upon her Asian neighbors. 32

$31_{\text {Kitamura, p. } 202 .}$ ${ }^{32}$ Taira, p. 230. 


\section{CHAPTER IV}

THE QUESTION OF REMILITARIZATION

Until the proclamation of the Nixon doctrine in 1969, the Japanese experienced the best of all possible worlds. They sat protected under the U.S. nuclear umbrella, expanded their economy at the world's fastest growth rate, made plans to develop an important military force, and traded profitably with China as well as with Peking's most hated enemies: Taiwan, the Soviet Union and the United States. Since about 1969, however, Japan has been searching for a new role, one that will be acceptable to her people and government, and to the peoples of Asia including China, the Soviet Union, and the United States. With the one possible exception of the U.S., probably every country in Asia opposes and fears (to some degree) the remilitarization of Japan. In part, the American role in Asia has been to act as a buffer between the other Asian Great Powers. An example of this is the less than 40,000 American troops stationed in South Korea. With the American presence in the southern part of the Korean pennisula, it is doubtful that a combination of any two Great Powers could successfully combine against a third. 
It is a stark reality of Asian power that China and Russia would prefer the American presence on the Korean peninsula to the Japanese. Given a choice between Japanese militarism and American militarism, the Chinese and Russians would choose the latter any time. 1

Perhaps the most important long-term question for Asian politics is concerned with the extent to which Japan will, in the future, remilitarize. Opinions on the subject vary from one extreme to the other. One observer has speculated that an,

examination of Japan's current international position and of her relations with her three largest neighbors-- the United States, the Soviet Union, and China-- suggest that the Japanese have neither the capability nor the intention of assuming a major politicalmilitary role and that close, cooperative ties with the United States continue to be the basis of their foreign policy. ${ }^{2}$

Another observer saw the response to Nixon's "dollar-shocks" of mid and late 1971, among both left and right in Japanese politics, as a sign that the United States was getting weak, and that Japan would in

$1_{\text {Hahm Pyong-choon, "Korea and the Emerging Asian }}$ Power Balance," Foreign Affairs (January 1972), p. 348.

2 Martin E. Weinstein, "Japan and the Continental Giants," Current History, (April 1971), p. 193. 
turn be forced to rearm. "The centre, however, which may for these purposes be taken to be the main body of the Liberal Democratic Party does not share the interpretation of the extremes." ${ }^{3}$ A third view felt it,

is essentially the lack of a cultural consensus as to the acceptable mode in which the balance of power is to be maintained among the Asian powers (the Soviet Union, China and Japan) that makes the prospect of international peace and stability in East Asia rather bleak. 4

Perhaps no one in Asia, including the Japanese, knew in mid-1972 the future limits of their remilitarization. The official government position on the question has been made clear a number of times. For example, in an article for the Jiyu Shimpo ${ }^{5}$ (the organ of the Liberal Democratic Party), in early June of 1972, Foreign Minister Fukuda said that Japan should stay economically strong but should never try to become a "military power." Specifically, a number of input factors are important to Japanese military-political considerations. Some of these factors are: the fear generated by the United States withdrawal in Asia; the demands of Japan's

3 "Right and Left Both See Rearmament," Economist, August 28, 1971, p. 27.

${ }^{4}$ Pyong-choon, p. 344 .

${ }^{5}$ See The Japan Times, June 7, 1972, p. 5. 
giant and modernized middle-class style economy; the modern history of Japan, usually finding it closely associated with a major world power; the fact that onethird of the present population was born after the Second World War; the elements of Japanese nationalism and a desire for big power status; the general instability in East Asia; that approximately 35 percent of all Japan's trade is with Asian countries; that the economic life of Japan depends upon open sea lanes; that there exists an expressed fear of Russian naval expansion; the importance of the growing power of the Japanese military-industrial complex; and finally, the constant need of Japan for an access to raw materials. Since Japan must import nearly ali needed fuels and minerals, an important element of weakness is the need for open access to raw materials and free access to the sea lanes. ${ }^{6}$ This raises the important question as to the degree of public acceptance of increased Japanese "protectionism" over their economy by military means.

Undoubtedly, a general feeling of national confidence has accompanied the economic boom, and there is a distinct danger of rising chauvinistic nationalism. Mishima's suicide was symptomatic of this, as is the enormous

${ }^{6}$ See pp. $52-54$ of this paper. 
proliferation of ultra-right-wing organizations (some 400 with more than 120,000 members). There has also been an increase in militaristic publications; and the controversies over educational policies and the restoration of Shintoism are other signs of the changing psychological atmosphere. 7

Although only the Japanese Socialist Party among the four major Opposition parties argues that Japan should not have an armed force, few elements within Japanese society seem to favor an extended re-militarization. The younger generation still seems determined that Japan can be a modern Great Power without having to become a military one. ${ }^{8}$ The "Japanization" of Asian security appeals neither to the majority of the Japanese public nor to the majority of the country's business sector. ${ }^{9}$ It is difficult to find any significant units of opinion outside the vocal right wing extremist groups who support a major military build-up in Japan. This attitude is particularly expressed by the Opposition parties. For example, while questioning Prime Minister Sato in the Diet on February 28, 1972, Junya Yano, Secretary General of the

7 T. C. Rhee, "Japan: Security and Militarism," World Today (September 1971), p. 395.

${ }^{8}$ Gibney, p. 103.

9 zbigniew Brzezinski, "Japan's Global Engagement," Foreign Affairs (January 1972), p. 274. 
Komeito, "expressed doubt if it is desirable that Japan continue its defense build-up when the U.S.-China rapprochement promises to reduce tensions in Asia." 10 Sato replied that Japan should have a capability to defend itself only to the point that it does not pose a threat to other countries.

The first one-half of the year 1972 was rocked by a series of "after-shocks" following, and related to, the American withdrawal in Asia and the resultant shift in the balance of power. The primary question for Japan's role in Asia has been linked to the question of military rearmament. There has been a heavy influx of agitation and opposition to the continued military build-up in the country. In the Diet, where many of these verbal battles have been fouqht, a sample survey over a two-month period, beginning in mid-February and lasting to midApril, discloses no fewer than four major political struggles.

The first such political struggle arising as an "after-shock" from the question of the newly expected remilitarized role for Japan was probably the most significant on a long-term basis. Beginning on February 8, 1972, the Opposition parties paralysed the Diet over the ${ }^{10}$ The Japan Times Weekly, March 4, 1972, p. 4. 
question of the amount of money requested in the 1972 defense bill. The paralysis of the Diet lasted for 18 days. Finally, on February 26, the Diet voted unanimously to significantly cut the amount requested for defense.

The second example occurred on March 9, 1972, when Japan awoke to the glaring newspaper headlines: "GSDF Unit 'Sneaks' into Tachikawa Base Under Cover of Night."11 The immediate question was over some eighty members of the Japanese Army (Ground Self-Defense Forces), who had in a surprise move, occupied the vacant U.S. Tachikawa Air Base early the previous morning. What had apparently upset the local population (the mayor had hired soundtrucks urging the populace to protest the action), was that a previous survey conducted by the Tachikawa Municipal Government in 1971 showed that 82 percent of the citizens opposed the use of the base by the GSDF. 12

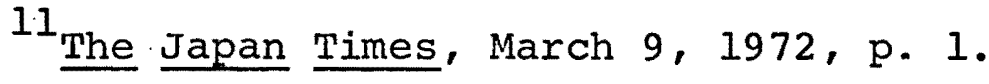

12 Ibid. , March 18, 1972, p. 2. In addition, the SDF in Japan are barely past the status of a public embarrassment. Most Japanese continue to think that a strong economy and a unified society are worth more than numerous divisions. "The need for armed forces may be understood by some, but not by many." See Gibney. p. 108 . 
At the same time that the local Tachikawa Government was arguing with the Defense Agency, the Opposition parties within the Diet had been angered by another announcement of the Self-Defense Forces (SDF) that the agency had carried 120 tons of equipment to Okinawa in preparation for reversion on May 15. Without first obtaining the approval of the National Defense Council (i.e., the supreme civilian body supervising defense affairs), a commercial freighter had been loaded, apparently in secret, on March 7. When the Diet discovered the incident three days later, the issue quickly became a question of military versus political power. On March 13, the Director General of the Defense Agency, after previously threatening to resign, "froze" the supplies on Okinawa and ordered their return to Japan. The government also promised to "reshuffle" those Defense Agency personnel concerned. 13

${ }^{13}$ In addition to the already existing problems over Okinawa reversion, the secret transfer of SDF supplies to that island created new ones. Those okinawians who belonged to reformist groups stepped up their protests against the deployment of SDF Units on the island, while even those who supported the stationing of the SDF on their island "have been confused by the clandestine transfer." See The Japan Times, March 14, 1972, p. 3 . 
The last major political incident to upset the country in this short two-month survey period was raised by a Socialist Dietman on April 13, when he disclosed what he claimed was a classified telegram of the U.S. Navy Department which read" that the U.S. and Japan had recently held talks towards creating a "naval bilateral nuclear force."14 The U.S. Embassy responded that the alleged plan for the force was a "faked document," and Prime Minister Sato catagorically denied that Japan and the U.S. had held such talks.

What exists in Japan today are two basically conflicting trends. On the one hand is a strong public fear over the question of remilitarization. This fear is generally held by the masses as well as most moderates and intellectuals. They feel that the best policy for Japan is neutrality. Paradoxically, this element also supports, to a certain degree, Japan's rearmament but only for means of limited "self-defense." The problem is that first group, who comprise the majority in Japan, have no clear-cut concept of what limits are defined by the term "defense." This confusion makes the group's position easily exploitable by the minority who articulate the second view in Japan today: complete

$$
{ }^{14} \text { Ibid., April 14, } 1972, \text { p. } 1 .
$$


remilitarization. This second group is small in numbers, but tightly knit in unity of discipline and purpose. In addition, the second group of,

industrial and financial circles have combined with the conservative wing of the ruling LDP to form what is tantamount to an 'industrial-politicalmilitary complex' for the apparent purpose of translating the new economic strength into the politicomilitary sphere. 15

The policy of the second group has been to gain the complete remilitarization of Japan, to be accomplished through two means: first, the gaining of increased public support; and second, the increasing of influence within the government. Success in this dual policy has been slower to come in gaining public support than in increasing influence within the government. Much of the representative elements in this second group are to be found in the more extreme right wing factions of the LDP. Moreover, the group has sufficient strength among the Liberal Democrats to influence Japan's foreign policy and military build-up in justification of its economic interests.

At the end of the second World war the entire country, including the big trusts (i.e., the "zaibatsu"), ${ }^{15}$ Rhee, p. 391. 
lay in complete ruin. As part of the democratization of Japan, the "zaibatsu" were to be either reduced or eliminated. This was necessary, it was felt, since the big Japanese trusts concentrated too much power in the hands of a few and were judged partially responsible as a prime factor in the political decisions leading to war. Many Japanese and foreign commentators charge today that the old "zaibatsu" are not dead, only revived. For example, such "zaibatsu" as the "Keidanren" and the "Nichikeiren" now publicly speak for Japan's rearmament. 16 The reasons given center not unexpectedly on the need for Japan to militarily safeguard its economic interests. There are, however, some distinctions between the "zaibatsu" of the post-war period and the trusts of the pre-war period. The most important change, according to Shozo Hotta President of the Sumitomo Bank and senior member of the core of the "zaibatsu" (the 16 presidents of the "White Water club"), is that among the post-war groups the holding company has disappeared. 17 The significance lies within a more independent management and a greatly reduced vertical control. Among other 16 Yiu, p. 235.

17 The New York Times, March 26, 1971, p. 1, 8. 
changes in today's "zaibatsu" are that: paternal authority has diminished, public ownership is now included, and, society in modern Japan is more decentralized. Nevertheless, and perhaps most important, is that "zaibatsu" has become today strong enough to influence the government of Japan toward greater military spending. 18

Although the "remilitarists" may or may not have succeeded in yet swaying public opinion to theix favor, it is not the public who makes national policy on a dayto-day basis. An example in the revival of an old spirit was felt in Tokyo on October 31, 1971, when the SDF, celebrating their 2lst anniversary, marched in review before Prime Minister Sato. Parading to a variety of imprésse foreigners and natives were groups,

of infantry, ranger and parachute troops, in battle dress, and of white capped seamen, airmen in blue helmets, cadets from the military academy that trains officers from all three services, and smartly turned out companies from the army's women's and nurses corps. Rumbling along behind on this sunny Sunday morning were medium and heavy tanks, trucks towing howitzers and missiles, engineer vehicles carrying rescue boats and portable bridges, and a reconnaissance troop in speckled camouflage uniforms aboard Honda motorcycles. ${ }^{19}$

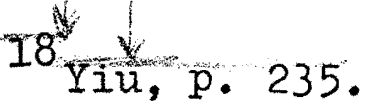
${ }^{19}$ The New York Times, November 1, 1971, p. 3. 
Japan is currently engaged in the Fourth Five Year Defense Plan, first announced on April 27, 1971, and expected to run through 1977. The Fourth Defense Plan is nominally limited by the same considerations that limited its predecessor, the Third Five Year Defense Plan. Both plans declared that defense capabilities should be enhanced in all three services, limited by domestic production and achieved with a minimal impact on the economy. Japan, however,

$$
\begin{aligned}
& \text { can be expected to take certain pre- } \\
& \text { cautionary steps to assure herself an } \\
& \text { intermediate degree of security: (i) } \\
& \text { continued expansion of the Self-Defense } \\
& \text { Forces (SDF), especially their naval } \\
& \text { and air components; (ii) continued re- } \\
& \text { search into missiles and nuclear energy; } \\
& \text { (iii) further steps towards a massive } \\
& \text { armaments industry, if and when it } \\
& \text { should become necessary; and (iv) the } \\
& \text { preparation of public opinion for these } \\
& \text { measures.20 }
\end{aligned}
$$

The new Defense Plan is to become effective on April 1, 1972, and made Japan the seventh largest spender on defense in the world, following the United States, the Soviet Union, the Feople's Republic of China, West Germany, France, and Great Britain. It also represents a 220 percent increase over the old outlay, and calls for an increase in the army from

$$
{ }^{20} \text { Rhee, pp. 390-391. }
$$


260,000 men to $271,000 \mathrm{men}$, an increase in the number of tanks to 990 , the constriction of two 8,000-ton helicopter-carrying escort vessels, and the construction of fourteen high-speed missile carriers and 61 other naval craft which will almost double the present size of the Japanese navy in total tonnage (i.e., from 144,000 tons to 247,000 tons). 21 In addition, the Fourth Defense Plan would acquire for Japan 170 new F4J Phantoms ${ }^{22}$ and urges the purchase of 920 new planes including 80 supersonic jet trainers. 23

Although the more general reactions from the two feuding Communist Asian giants to Japan's recent power ambitions in Asia will be discussed more fully below, some immediate reaction might be useful at this point. The Peking Review, published under the title "Japanese Militarism Back in the Saddle," a copy from a Japanese "white paper" concerning the growth of Japanese military spending. The figures on page 71 disclose not only a steady pattern of growth in spending throughout the entire period, but also that, since 1969 (the year of the Nixon doctrine), the pattern of growth spending was broken by sharp increases.
$21_{\text {The New York Times, April 28, 1971, p. } 7 .}$.
22 Weinstein, p. 194.
23 Ibid. 
TABLE V

JAPAN'S ANNUAL DEFENSE SPENDING:

$1950-1971^{24}$

(Given in millions of yen)

\begin{tabular}{llll}
\hline 1950 & 129,300 & 1961 & 183,500 \\
1951 & 126,600 & 1962 & 213,800 \\
1952 & 182,600 & 1963 & 247,500 \\
1953 & 125,500 & 1964 & 280,800 \\
1954 & 135,000 & 1965 & 350,400 \\
1955 & 134,900 & 1966 & 345,100 \\
1956 & 142,900 & 1967 & 387,000 \\
1957 & 143,600 & 1968 & 422,100 \\
1958 & 148,400 & 1969 & 483,800 \\
1959 & 155,700 & 1970 & 569,500 \\
1960 & 160,000 & 1971 & 670,900 \\
\hline
\end{tabular}

Given at the old rate of 360 yen = one dollar.

Generally, the past policy of China in dealing with the question of Japanese militarism has been an attempt to force a split between that country and the U.S. Today, this policy by China may have been reversed in view of the danger that such a split could necessitate an increase in defense spending by Japan. In fact, fear of Japan may well have been one of the motives for Peking's recent moves toward "detente" with the United States. Although the Japanese military budget in proportional terms

24 "Japanese Militarism Back in the Saddle," Peking Review, No. 5, January 29, 1971, pp. 20-21. 
is the smallest of the major powers (less than 1 percent of the total Japanese Gross National Product), the Japanese economy already dominates areas of great sensitivity to China (especially Taiwan and South Korea). China's attacks on Japan's late's't policies are important for several reasons, which include among them the need for a neutralization of a potentially hostile Japan, especially if faced with a realization in the Russian threat. In addition, "Peking views, regarding Taiwan, Japan's trade and investment in the island and the historic orientation of the Taiwanese toward Japan as the chief stimulants to continued separatism there." 25 The future question to be answered by the Chinese leadership while simultaneously remembering the Japanese role in the inter-war period, is whether or not Japan is prepared today to defend its economic empire in Asia through military means. ${ }^{26}$

Both China and the Soviet Union have referred to the reversion of Okinawa as the "Okinawinization of Japan."27 Infother words, both Russia and China see

Edwinto. Reischauer, "Fateful Triangle-- The United States, Japan and China," The New York Times, Section IV, September 19, 1971, p. 13.

\section{Ibid.}

$27_{\text {For example, see The Current Digest of the Soviet }}$ Press, Vol. XXIII, No. 23, July 6, 1971, p. $\frac{16}{16}$. 
the acquisition by Japan of Okinawa and its huge military bases as a significant step by that country towards total remilitarization. As early as December 16, 1969, Pravda was writting in reference to the Nixon-Sato Guam meeting that up to then, the post-war expansion of Japanese militarism in Asia had been largely economic in nature. The talks between Nixon and Sato indicated "that Japan's ruling circles are now ready to reinforce economic penetration by political means and; if necessary, by military means as well."28 In June of 1969, another Soviet writer had also indicated fears over the growing military, since,

Japanese monopolies are actively working to strengthen ASPAC economically and militarily . . . Now Japan's military circles are giving strong support to plans to set up a Pacific military alliance-- PATO. Washington wants (the article claimed). . 18 with Japan's aid, to turn PATO into a 'superbloc' spearheaded against the USSR. 29

A more recent article in Izvestia entitled: "Arm, Arm, and Arm some More," published in April of 1971, p. 3 .

${ }^{28}$ Ibid., Vol. XXI, No. 50, January 13, 1970,

29 I. Sergienko, "Japanese Nilitarism Raises

Its Head," International Affairs (June 1969), p. 33. 
asked in reference to the drafted new military buildup plan:

Why does Japan need a strong army? The authors of the draft explain that it will be charged with the task of participating in 'limited local wars.' What they mean by those words can only be guessed. But it is perfectly obvious that the NDA (National Defense Agency) is beginning to ready a military machine for actions 30 that can in no way be called defensive.

Another article published in Moscow was entitled: "The Tokyo Trial: A Reminder." It issued a warning which could hardly be mistaken in Tokyo. After noting the twenty-fifth anniversary of the Tokyo Trial (i.e., from May 3, 1946 to November 12, 1946), the article saw,

the same tendencies endangering peace, which ultimately brought the major war criminals into the dock in 1946 . . . once again appearing and developing in the country where these men were tried. 31

If continued, Japanese rearmament would "acquire a dangerous significance." In particular,

the extensive rearmament programme is designed to boost the expansion of Japanese monopolies in Southeast Asia. That was revealed last autumn (1970). .

30 "Arm, Arm, and Arm Some More," The Current Digest of the Soviet Press, Vol. XXIII, No. 17, May 25, 1971, p. 39. (See also Izvestia, April 30, 1971, p. 2.)

$31_{S}$. Budkevich and M. Rahinsky, "The Tokyo Trial: A Reminder," International Affairs, (August 1971), p. 74. 
by Nakasone, chief of the National Defense Agency who said: 'Japan will actively invest her capital in Southeast Asia and own sizeable assets $i_{i 1}$ this area. This will give rise to rights and interests and a vital frontier. In order to defend them, Japan will eventually require military strength!'32

The article also claimed that: .

there are many men among the ruling circles of present-day Japan who refuse to reckon with the experience of history and its lessons, and who have taken a policy of revenge as a guide to action. 33

Finally, for,

those who seek to reverse the tide of history, those who ignore the lessons of history and take the way traveled by Tojo, Hagaki, and their like, the Tokyo Trial and the judgment of the International Military Tribunal for the Far East is a grim warning. 34

What in effect is usually meant by the term "complete remilitarization" is usually meant both the conventional, as well as nuclear rearming of Japan. By 1972, Japan had accumulated some experience and a sizeable mass of data on weapons technology in nuclear systems building and associated delivery systems. Japan has, through 1972, kept open its options on building a Ibid. 33 Ibid., p. 76 . ${ }^{34}$ Ibid., p. 107. 
nuclear stockpile and could in no less than six months from the time of the political decision have a sizeable arsenal. 35

The realization of the political decision to begin building a nuclear arsenal could be brought about given the proper stimuli. For example:

If the big powers continue to use nuclear capability as the yardstick of strength, Japan one day may feel compelled to go nuclear. This sobering note of warning was struck recently by Kiichi Miyazawa, former Minister of International Trade and Induştry and one of Japan's elder statesmen. 36

The official government position was expressed by Foreign Minister Fukuda who said that Japan has a "nuclear allergy." He also stated that he felt Japan, should not have nuclear arms or any substantial military means. Being an economic power, but declining to be a military power, we have a certain reserve of power. We can use it for the development of the less advanced part of the world. . . 37

One reason Japan fears becoming a nuclear military power is directly linked to its geographic liabilities.

${ }^{35}$ The New York Times, December 26, 1971, p. 22. ${ }^{36}$ Far Eastern Economic Review, December 18, 1971, p. 21 .

37 "Who Will Succeed Sato in Japan? Interviews with Three Top Contenders," Newsweek, May 15, 1972, pp. 4445 . 
The vast majority of Japan's population and industry are concentrated into a small area and are an easy target for nuclear attack. Japan is also a difficult country to defend since, unlike the United States, China, or the Soviet Union, its total area is small, and with few relatively unoccupied areas, it would not take many hydrogen bombs to completely saturate all three main islands. Keeping this in mind, neither can one forget that the only atomic weapons ever actually used in warfare were dropped on Japan. This factor has left the Governments and people of Japan psychologically squeamish in any association to anything "nuclear." In this sense, the policy in Japan from 1945 to 1972 has been an aversion to the nuclear question, and even undue caution when dealing in diplomacy with the nuclear powers. The policy of Prime Minister Sato has been to keep Japan's involvement in international issues at a minimum, thereby hoping to keep Japan away as far as possible from active involvement in any general war. It was the "post-war nuclear fear" that pressed Japan to extract from President Nixon a promise to remove all nuclear weapons from Okinawa prior to reversion. In addition, it has been also the past policy of Japan to keep open at least economic ties with the Communist countries. This was in part desiqned to avoid too close 
an association and involvement with the foreign policies of any one nuclear power.

If "nuclear aversion" has been linked to the post-war period in Japan, and, as Prime Minister Sato and others have said, the revertion of okinawa in May of 1972 ended the post-war era for Japan; does that mean that the nuclear aversion has ended also? Recent indications of Japanese public opinion may in fact be following the pattern previously set regarding the acquision of conventional arms. In other words, the old antipathy to "nuclearization" may have ended as Japan enters its new role in Asia. Most people in Japan today now believe the country will go nuclear over the next decade. 38

Today, in the view of many government officials and industrialists who keep their fingers on the public pulse here, the emotional antipathy of the Japanese to things nuclear has all but vanished. . While emotional and political opposition to things nuclear is dying, Japanese technical skills in the nuclear field are rapidly increasing, including the capacity to make nuclear weapons.

Today, about one-third of the population in Japan

\footnotetext{
38"Missing Superpower," Economist, July 31, 1971, p. 14 .

${ }^{39}$ The New York Times, December 26, 1971, p. 22.
} 
feels nuclear weapons for the country acceptable if not desirable. 40

As previously indicated, a variety of Western values and incentives were "grafted" on Japan. These graftings included democratic principals as well as a general demilitarization. The latter declared the Japanese people to forever renounce war as a sovereign right of the nation. However, these stipulations presumed at least two conditions: first, that the policy implemented from above by the American Supreme Commander would actually take hold; and second, that Japan would henceforth and indefinitely be protected by American military power. Democracy and demilitarization were designed to be instilled in the Japanese by two means: by law and by attitude. If the attitudes of the Japanese people towards militarization and nuclearization are changing, is it possible that the simultaneously instilled attitudes towards democracy, are concomitantly changing?

It was Article IX in the 1947 Constitution of Japan that renounced the right for the country to ever maintain air, sea or land forces or other war potential. This so-called "pacifist clause" was, however, rendered ${ }^{40}$ Ibid. 
ineffective long ago with the development of the "Self-Defense Forces." A second guard against reversion to the old pre-war path of militarism was to be found in Article 96, designed to make constitutional revision difficult. It requires "on the part of those favoring it not only the necessary support in the Diet but also real confidence that public opinion is on their side."4l Yet, in the end. legal considerations may be of little significance, although many people in Japan consider them a safeguard against nuclearization. This is because, "contrary to widespread opinion, there is nothing in the Japanese Constitution that specifically prohibits nuclear weapons." 42 The only viable defense of democracy and demilitarization lie outside of the constitutions and codes, and within the attitudes of the people. If the people of Japan have not yet acquired an attitude for the values of democracy and peace, no paper constitution will be able to secure it for them.

The real arguments against nuclearization for Japan today stem from practical considerations. The advocates

${ }^{41}$ R. Storry. "Options for Japan in the 1970 's," World Today. (August 1970), p. 325 .

42 The New York Times, December 26, 1971, p. 22.

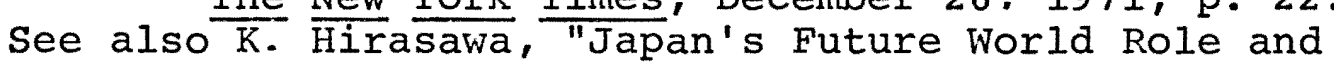
Japanese-American Relations," Orbis (Spring 1971). p. 341. 
against nuclearization cite such considerations as: Japan's vulnerable position to nuclear attack with 90 percent of the population situated on a 100-mile belt; Japan cannot hope to catch up with U.S. and Soviet missile technology and could never really expect to acquire a "second-strike" capacity; and, Japan, as a nuclear power, would probably friqhten the other Asian nations, in turn having a negative affect on business. Nevertheless, as noted, indications are increasing that with the U.S. Withdrawal, the nuclear threat from China, and the desire of many Japanese to gain Superpower status, Japan may in fact be "forced" to acquire nuclear capacity. Popular magazines in Japan today carry articles giving the pro and cons on the nuclear question, antinuclear demonstrations find fewer participants each year, and with the younger generation having no direct memory of Nagasaki and Hiroshima, nuclear science is attracting increasing numbers of young students. ${ }^{43}$ In addition to the building of nuclear power plants designed to help safisfy Japan's peaceful fuel needs, the country is expected to complete late in 1972 its first nuclear ship (the fourth non-warship of its kind in the world).

${ }^{43}$ The New York Times, December 26, 1971, p. 22. 
Finally, there still exists the larqer question of democracy itself as a viable institution in a peaceful Japan. One observer has suggested that there is, widespread criticism of the Constitution as 'an alien and impraqtical' document, and strong demands, especially among leading members of the LDP, for official recognition of the Emperor as the Head of State, with the Cabinet directly responsible to him or, more correctly, to the powers behind the throne, as during the Meiji oligarchy. Indeed. the Meiji Constitution is being cited as the model for future constitutional amendments. 44

This, in fact, may be the future case for Japan.

In October of 1971, it was reported that the ruling LDP is moving towards a proposal for a thorough revision of the present Constitution.

Osamu Inaba, chairman of the party committee drafting the revision, said the major changes would be proposed in the famous 'no war' article, in controls over military forces, the political position of the Emperor, and perhaps in the structure of the Diet, or Parliament. 45

The change in the Emperor's position would be from the present status as "the symbol of the state and the unity of the people," to renaming him as the head of state. The party chairman also noted:

${ }^{44}$ Rhee, pp. 395-396.

${ }^{45}$ The New York Times, October 30, 1971, p. 11. 
the Emperor as head of state in the Constitution would reflect a resurgence of national pride and confidence among the Japanese and would be another return to traditional concepts as the Japanese seek their national identity. 46

Thus, the fear of the political and military return by Japan to the pre-war structure appears a valid one.

Japan's democratic foundation is extremely shallow despite its successful facade and there is still a wide popular belief that affairs of state should be managed by 'those who know best.' 47

Other observers disagree, suggesting that if Japanese nationalism revives it probably will not be centered around the monarchy, but will, rather, center around the Japanese race. 48

\footnotetext{
${ }^{46}$ Ibid.

47 Rhee, p. 397.

${ }^{48}$ storry, p. 333 .
} 
CHAPTER V

\section{JAPAN-UNITED STATES \\ REIATIONS}

Following the defeat of Japan in 1945, the American occupation forces attempted to transform the country's basic attitudes by laying a base from which a democratic and peaceful society could be built. Specifically, the transformation of Japanese society saw the ultimate objectives of peace and democracy to be achieved by: (1) applying the democratic concept in education; (2) encouraging a wide distribution of income and ownership throughout the population in the means of production and trade; (3) the elimination from office and punishment of those persons associated closely with Japan's militaristic policies at home and abroad; (4) limiting Japan's sovereignty to only the immediate home islands; and, (5) the destruction of the military establishment and its economic base. Since under these conditions Japan would not be able to defend itself, on September 8, 1951, the United States signed the Treaty of Peace and Mutual Security, guaranteeing its security. Although both Article IX (i.e., the "no-war clause") of the Japanese Constitution 
and the Security Treaty pledged Japan to live peacefully with other nations and to settle disputes only by amicable means, the treaty was modified to read that Japan was not to be deprived of "the right of individual and collective self-defense." At the same time, the Security Treaty with the United States (as with similar treaties involving Australia, New Zealand and the Philippines) did not obligate Japan to assist in the defense of that country should any of its territory or armed forces be attacked. In addition to being renewed in 1960, the Security Treaty was also revised in that the United States would now consult with Japan before using its bases for war or before introducing nuclear weapons. In November of 1969 the Security Treaty was transformed into the Treaty of Mutual Cooperation and Security. In a joint message by President Nixon and Prime Minister Sato, the new security treaty was to be continued indefinitely beyond its June 1970 expiration date. It was also altered to read that either party could now terminate the treaty whenever so desired.

The meeting in 1969 between President Nixon and Prime Minister Sato also produced other results. The most important of these included an agreement for the 
1972 reversion of Okinawa, and raised Sato's domestic popularity to an all-time high. Sato was so exuberated with this triumph he declared in a speech that, henceforth, it would be considered that the "security of the Republic of Korea was essential to Japan's security," and, in addition, that the security of Taiwan was also a most important factor in the security of Japan.

Since Sato's 1969 speech tying together Japanese security to the security of Taiwan and South Korea, world conditions and conditions in Japan have drastically altered. Until 1969 the conservative Governments of Japan had centered their foreign policies on close political, economic, and military ties with the United States. They saw the Soviet Union as the principal threat to their security and believed that economic growth depended on successfully countering this threat 2 In addition, before and through 1969, the United States had acted as a tremendous supplier of raw materials to Japan and as a huge market for Japanese exports. In

${ }^{1}$ See The New York Times, November 22,1969, p. 14, for complete text.

${ }^{2}$ Weinstein, p. 195. 
military terms, American air, sea and land forces largely protected Japan's access to the resources and markets of the non-Communist world.

On the economic level, the supremacy of the United States has been lost since 1969. The American economy no longer controls the once numerous export markets, no longer unquestionably controls such vast accumulations of raw materials, and no longer can out-compete other countries nearly at will. On the political level, both the "detente" with China and the less than careful manner in which it was carried out, have, when combined, pushed Japan and the United States apart, with both casting aside the old beneficial roles that each had played.

The fact that Japan has gradually in the past 20 years outgrown the old relationship which had cast the country as a junior American partner, could probably not have been avoided by any American administration. The problems of American-Japanese relations go far beyond those enumerated in this paper. ${ }^{3}$ Many of these problems find their source deep in the over-commitments

${ }^{3}$ One could even liken Japan's investing role in Vietnam and the economic benefits which were derived, to the similar role the United States played as a supplier to the Allies in World War $I$. 
of the American role in Vietnam. ${ }^{4}$

Specifically, the four "shocks" which might have been blunted in intensity through more careful advance preparation and more gentle application, were: (1) the sudden and last minute announcemént of Nixon's Peking trip; (2) the severe economic measures (the suspension of dollar conversion and a 10 percent surcharge openly aimed at Japan), and yen revaluation; (3) the imposition of textile quotas; and, (4) the success of getting Japan to co-sponsor the United Nation motion allowing Taiwan to keep its membership, which then dramatically failed. In the face of this, stability in the Asian region may nevertheless be inconceivable without a continuing, close, cooperative relationship between Japan and the United States

In a statement by President Nixon made in Bangkok, Thailand, on July 28, 1969, the Nixon doctrine was explained for its Asian implications:

What we seek for Asia is a community of free nations able to go their own way and

${ }^{4}$ Neither does this paper find itself in dispute with those world-wide international issues and policies conductea by the United States from 1968 through 1972, extending far beyond the immediate scope of this paper. ${ }^{5}$ Hirasawa, p. 338 . 
seek their own destiny with whatever cooperation we can provide-- a community of independent Asian countries, developing through mutual cooperation. 6

The President further added:

our cooperation with Japan will be crucial to our efforts to help other Asian nations develop in peace. Japan's partnership with us will be a key to the success of the Nixon Doctrine in Asia.7

The Nixon doctrine as originally enumerated on Guam, draws a distinction between those countries which are not industrialized and where American defense commitments must be limited, and those countries which are industrialized like Japan, Australia, and Western Europe where commitments are greater.

If Japan's partnership with the United States is the "key to the success of the Nixon Doctrine in Asia," and the President's methods in arriving at a "detente" with China went far to destroy that very partnership, how was such a policy to be explained? The attempt was made by President Nixon in a statement to the Congress on February 9, 1972:

For our part, we have made it clear that our aim in Peking is to establish a

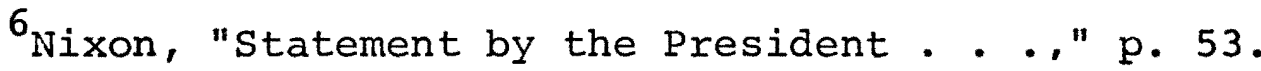
Ibid. . p. 58 . 
better mutual understanding of one another's policies. We will not seek or discuss bilateral arrangements that could adversely affect the interests of our allies. We have no interest in arrangements which would sacrifice our friendship with a lonq-standing ally to the need for better communication with a long-standing adversary. 8

More specifically, Nixon apologized that we:

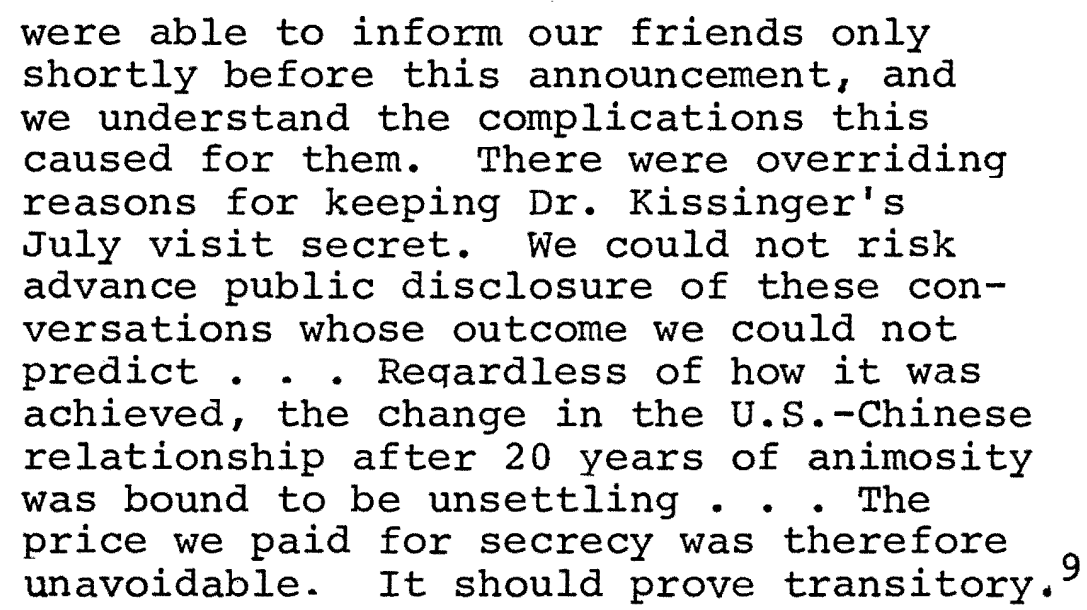

These statements create more questions than they answer. Was Prime Minister Sato of Japan not expected to be able to keep such an important secret? Surely Sato, following his removal from the post of Prime Minister would not find the "unsettling" change as "transitory." Finally, a price could in fact be expected to be paid in Japanese-American relations, but the vital question to be answered is whether the p. 341 .

${ }^{8}$ Nixon, "U.S. Foreign Policy for the 1970's...," ${ }^{9}$ Ibid.. p. 329. 
improvement in Chinese relations was worth the price paid by America or whether it came too high.

Following the Nixon visit to China, Marshall

Green, the Assistant Secretary for East Asia and

Pacific Affairs, was sent to the region in an effort to

bolster sagging spirits and reassure doubting allies.

With his return to the United States he appeared before

the House Committee on Foreign Affairs and reported

that he,

detected considerable concern, not about our government's intention to provide adequate assistance under the Nixon doctrine, but rather about its ability to do so in the face of what appears to them a growing anti-aid attitude in the United States. There is indeed much concern lest our programs of support for Asian nations decline too rapidly. They are watching closely to see exactly what we mean when we say that we stand by our commitments and that we intend to remain a Pacific power. 10

Several days later the Assistant Secretary again publically appeared, this time on the television show, "Meet the Press." In reply to a question, Assistant Secretary Green enumerated another fear that had arisen

10 Marshall Green, Assistant Secretary for East Asian and Pacific Affairs, "Security Assistance for East Asia and the Long-Range U.S. Interests. Made before the House Committee on Foreign Affairs on March 23, 1972," The Department of State Bulletin, Vol. LXVI, No. 1712, Apri1 $17,1972, \frac{1}{\text { p. }} \frac{\text { St9. }}{579}$ 
from the conduct of recent American actions in Asia:

The question of whether there were any secret deals, for example, whether there were any kinds of negotiations behind their back; and I think I was able to prove convincingly that there was not. 11

Neither the premise of no secret deals having been made, nor the conclusion that all were convinced by the Assistant Secretary, has yet been proven. Today in Japan and in Asia those very two fears remain. Perhaps the primary example in the reduction of American Pacific power outside of Vietnam itself, is the retired position of the United States in Okinawa. Actually, Okinawa represents only the last of several territories returned by America since the war. The Amami Islands lying south of Kyushu, were returned to Japan in December of 1954. In June of 1968, the Bonin Islands, which includes Iow-Jima, were returned. Okinawa was returned'in 1972 and became Japan's 47th Prefecture.

The United States still has, as of 1972, 101 military installations in Japan, 80 of them in Okinawa. More importantly, Okinawa serves as the nerve center for United States defense in the Pacific. By reverting the military complex back to the

11"Assistant Secretary Green Interviewed on Meet the Press," ibid. , p. 572. 
administrative control of Japan, the U.S. is now limited to "prior approval" from that. country before the implementation of any American military initiative. The reversion of American "military sovereignty" in Okinawa means the U.S. must now consult with Japan before increasing military strength on any of its "Japanese" bases, before making any majorequipment changes, or before directing combat military operations from those bases. Reversion also adds Okinawa to the list of Asian countries in which the U.S. may not store nuclear weapons. Moreover, since Taiwan is also "nuclear free," the U.S. must now depend on South Korea and the Philippines, in addition to several other minor South East Asian areas, for nuclear deployment.

The concession of military sovereignty by the United States in the reversion of Okinawa was also designed to provide positive results. By ending American occupation of former Japanese territory, America was making good on its pledge of no territorial gains from World War II. In addition, by reverting Okinawa, it was hoped that a source of tension would be eliminated, in addition to also establishing diplomatic equality between the United States and Japan. However, Japan can' never be truly equal to the U.S. as long as any American 
military bases exist anywhere on Japanese territory. Moreover, it appears that the reversion of Okinawan administration to Japan may actually increase tensions, since the purpose of Okinawa for the U.S. is obviously military, while any American military operations from "Japanese soil" simultaneously "implicate" Japan, and are therefore resented.

Okinawa if not handled careful by both sides could turn into an easily exploitable political issue. Indications are that Japan will seek in the future an even closer control over American military movement to, from, and within the country. ${ }^{12}$ This action would go far to impair American military effectiveness in Asia and could produce a conflict of interest, as long as America has important interests in Asia.

Some earlier problems over the new status of Okinawa have already arisen. For example, B-52 bombers might be permanently banned from use in Okinawa, thereby forcing the U.S. to rely on either Guam or Thailand. The question of how long Thailand will remain secure to American forces is an interesting one, while Guam is hundreds of extra miles from both Southeast Asia and

\section{${ }^{12}$ The Japan Times, April 26, 1971. p. 1.}


South Korea. Although Guam is an American territory, the other islands are held under a United Nations trusteeship with their future unresolved.

Problems over American-Japanese co-rule had appeared even before Okinawa had been returned. While the Japanese Communist Party opposed the conditions of the agreement returning okinawa, the Japanese Socialist Party claimed that the reversion of okinawa "at the hands of the sato Cabinet and the U.S. Government is deceptive because it tramples underfoot the okinawans' wish for an unconditional reversion."13 without unconditional reversion, the complaint went, there was a chance that Japan might be drawn into a war. The Komeito did express some support for the American return of the islands, but added that "the strong desire for the elimination of everything that might lead to war and for guaranteed basic rights for the Okinawans" 14 were not fully satisfied. The Democratic Socialist Party followed the same policy line as the others, criticizing the U.S. base rights in Okinawa.

All the Diet members from both the Japan Socialist Party and the Japan Communist Party, as well as the

$$
\begin{aligned}
& 13 \text { Ibid. , May } 15,1972, \text { p. } 1 . \\
& { }^{14} \text { Ibid. }
\end{aligned}
$$


seven Dietmen elected from Okinawa, boycotted the government-sponsored ceremonies celebrating reversion. The other two parties attended the ceremonies, but added that they would probably join any new campaign designed to "improve" the terms of the Okinawan agreement. 15

Within days following the American return of the islands, problems were already building over what degree Japanese authorities would allow the United States to use its bases on the island. The government expressed fear that it might be "drawn into" the war in Vietnam, since the U.S. continued to use its bases at several locations in Japan to: (1) conduct a midair refueling of Vietnam-bound B-52's by planes based on Okinawa; (2) transfer F-4 Phantom jets from Iwakuni Air Base to Vietnam; (3) sail U.S. naval ships then in port from Yokosuka to the South China Sea; and, (4) bring tanks from Vietnam to American bases for the purpose of conducting repairs. ${ }^{16}$ In reply to the Japanese fear, a:

U.S. State Department official said that the U.S. Would expect an affirmative reply

${ }^{15}$ Ibid., May 14, 1972 , p. 2.

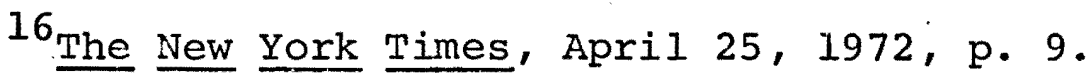


from Japan to a request for permission to use U.S. military bases in Japan, including those in okinawa, for combat operations. 17

Although President Nixon and Prime Minister Sato exchanged friendly greetings during the okinawan reversion ceremonies using the newly installed "hot line" between the countries for the first time, the real significance in policy direction for the United States following reversion was that it represented a very significant step in the dismantling of the American containment of China. Since Okinawa lies close off the China coast, any increased responsibilities for Japan within the confines of the important military base could hardly serve to better Japan-China relations. Not only was the reversion important in American foreign policy, but following its celebration, China reduced its quanity and strength of criticism directed against the JapaneseU.S. Security Treaty. ${ }^{18}$ The leadership of China realize that they have as much to lose from the remilitarization of Japan as anyone in Asia.

In 1972 American-Japanese relations were at their lowest point since the end of the war. Part of the problem is personal with the Nixon Administration. There:

$$
\begin{aligned}
& \text { 17 The Japan Times, March 17, 1971, p. } 1 . \\
& { }^{18} \text { Ibid. , May 16, 1972, p. } 1 .
\end{aligned}
$$


is a distinct opinion existing in Japan

that Dr. Kissinger is 'anti-Japanese,' that he does not know Asia and makes light of it. Kissinger is seen as a 'Machiavellian type' who is distrusted by many Japanese based on his role in Nixon's Asian policies. 19

A second major complaint was that although Kissinger had had time to go to Peking to arrange through secret talks with Chinese leaders for Nixon's visit, he seemed to have no time to visit America's most important ally in Asia. From April 20 through April 24 of 1972, Kissinger was in Moscow (after having cancelled a trip to Japan over the Vietnam question), for secret talks with Soviet leaders on the upcoming Nixon Summit conference. Dr. Kissinger did not finally arrive in Japan until mid-June, after a second postponment in May over the Moscow trip. Moreover, the Kissinger delays to Japan were seen as:

$$
\begin{aligned}
& \text { another instance of the United States' } \\
& \text { growing indifference to its Asian ally . . . } \\
& \text { The conclusion here is that the White } \\
& \text { House has shifted the terms of the } \\
& \text { Japanese alliance to its own advantage } \\
& \text { and invited Japan to take it or leave } \\
& \text { it. 'I think Mr. Kissinger sees us as } \\
& \text { a childish and emotional country, and } \\
& \text { he is proceeding on that basis,' a } \\
& \text { senior Foreign Ministry official said. . .20 }
\end{aligned}
$$

In addition, the Japanese see Kissinger as the embodiment of the anti-Japanese mood, insensitive to modern Japan

$$
\begin{aligned}
& { }^{19} \text { The Japan Times Weekly, April 22, } 1972, \text { p. } 3 . \\
& { }^{20} \text { The New York Times, April 15, 1972, p. } 9 .
\end{aligned}
$$


"and willing to cast Japan as a rival instead of an ally . . . "2l

Other problems have been raised by other prominent Americans and their statements of attitude. For example, a row was touched off by the remarks of Defense Secretary Melvin Laird when they were interpeted in Japan as advocating the acquision by that country of nuclear weapons. The Defense Secretary, after noting that the U.S. now provides Japan's nuclear shield, added that:

I believe in that area of the world they have a greater responsibility . . . I believe that they should be bearing a greater responsibility for the economic as well as the military burden of defending peace and maintaining the security of that area of the world. 22

President Nixon's personal embarrassment of Sato

on a one-to-one basis, however, was probably in an immediate sense, the most damaging.

In Washington, President Nixon's unilateral moves on China, the yen, and textiles last year are seen to reflect hostility against Premeir Eisaku Sato, who reneged on his 1969 promise to curb textile exports after Nixon pledged Okinawa's return. But to the Japanese, it was not their 'lameduck' premier, but Japan that was ignored. The

${ }^{21}$ Ibid.

22 The Japan Times, May 21,1972 , p. 4. 
Nixon 'shocks' are regarded as a national humiliation. 23

When Prime Minister Sato was asked for his response as he sat watching a worldwide broadcast over television of the Nixon visit to Peking, he replied "disdainfully" that "President Nixon himself claims it's an epoch-making event." Then, "in a voice iced with sarcasm he added: 'If he says so, how can we dispute it?'" 24

The response to Nixon's China-shock among the leading candidates seeking to replace sato in July of 1972 was quite uniform. Sato's own choice, Foreign Minister Takeo Fukuda, replied that as:

far as President Nixon's visit to China
is concerned, I certainly welcome it.
But the way it was done, in the sudden,
abrupt manner-- is not something I
really appreciate. - . it should never
be repeated.25 A second major contender and the man who replaced Sato as Prime Minister was Kakuei Tanaka, Minister of International Trade and Industry. He observed that the:

Japanese are a very cautious people. The kind of move Mr. Nixon made to Red China without reference to Japan-- this is not

\footnotetext{
p. The Harold International Tribune, April 26, 1972 , p. 4

24 Newsweek. March 6, 1972, p. 4.

${ }^{25}$ Ibid., May 15, 1972, pp. 44-45.
} 
the way we would have done it. We would have given you advance notice. Courtesy is something. Orientals respect. 26

A third contender for the post was former Foreign Minister Masayoshi Ohira, who correctly noted that in:

the international sphere, changes are in order. From now on, Japan will not be able to depend too much on the U.S., and I believe the U.S. desires Japan to be more self-supporting.. The U.S. does not have the power anymore to limitlessly assist various countries around the globe with its goodwill. We have developed our national power and the U.S. wants to reduce her over-commitment. These two factors will work as an impetus to change the U.S.-Japanese relationship. 27

A fourth high-ranking Japanese official called President Nixon's China-shock a Pearl Harbor in reverse. He added that the abrupt "announcement set back Japanese-American relations by ten years." 28

In part, the American initiative with China can be seen as a negative reaction to the economic threat from Japan. The Japanese government has estimated that by 1980, Sino-Japanese trade could reach $\$ 3,200$ million. What Japan fears is that an American entry into the China market, especially into the areas of machine tools,

26

Ibid.

27

Ibid.

28 The New York Times, August 4, 1971, p. 1.

29

Far Eastern Economic Review, March 4, 1972, p. 4. 
aircraft and generators, will threaten their position. Some Japanese expect Sino-American trade within three years to reach $\$ 200$ million.

To many Japanese it would appear today that, after ti.... having been forced into the American picture of containing China throughout the 1950's and 1960's, the United States had now blithely turned its back, leaving Japan alone, in a precarious position to find its own solutions to the Cold War riddle. Politically and psychologically:

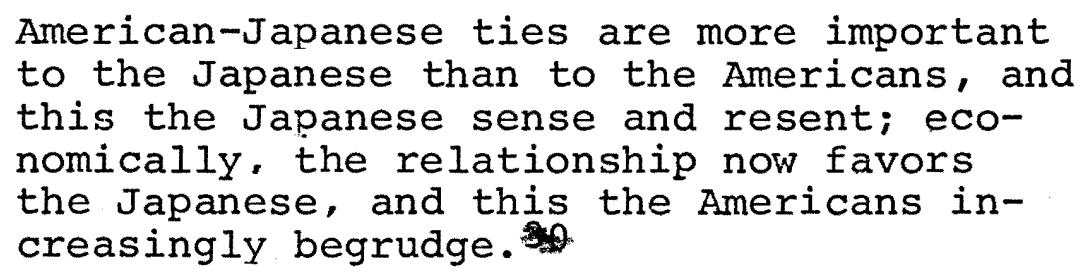

Therefore, while the United States has attempted to force through an economic readjustment between the two countries, the Japanese have been moving to redress the political, psychological and military imbalance. The net affect upon Japan has, in some ways, been highly beneficial. While the American initiative towards China has left a brightly lit path for Japan to follow, the Soviet Union has also become less intractable to Tokyo. While relations between China and Japan may soon ${ }^{30}$ Brzezinski, p. 270 . 
be normalized, relations between Japan and the Soviet Union may soon see a signing of a peace treaty and other mutually beneficial actions.

In addition, the new independent policy has obtained for Japan other diplomatic objectives. On February 19, 1972, Japan and the Mongolian People's Republic announced the establishment of diplomatic relations. This was the first time that Japan had established diplomatic relations with a Communist country in Asia. Tokyo has also since the Nixon "shocks," been unafraid to open contacts with both North Vietnam and North Korea. As in the case of a Japanese delegation to Hanoi and without informing Washington beforehand, the Sato administration in February and March of 1972 began moving towards the recognition of Bangladesh, a country to which up to that time the U.S. had totally ignored. At the conclusion of the Sapporo Olympics, the head of the North Korean delegation stayed on in Japan to host a series of lavish receptions to honor the newly formed Korea-Japan Export and Import Corporation. Simultaneously, Socialist Governor Ryokichi Minobe invited a group of ranking North Koreans to pay an unprecedented visit to Tokyo.

These actions are an obvious indication that Japan now feels the U.S. is probably no longer totally 
reliable. Shocked at being excluded in a major policy alteration which drastically affected Japan itself, the Japanese now fear being played off against China.

The Nixon initiative toward Peking violated the spirit, if not the letter, of the principle of joint consultation, and it is guite likely that in the future it will be more difficult for the two capitals to concert their policies. 31

In in the long run, good for the American interest even if it only allows the United States to escape its own containment policy which rigid anti-Communism demanded. The United States has now found new flexibility in foreign policy which previously it had denied itself. In part, this new flexible position was born of necessity, since the United States in the 1970's finds it no longer has quite the ability to pressure others into a partnership of its own will.

${ }^{31_{\text {Ibid. }}, \text { p. } 272 .}$ 
CHAPTER VI

JAPAN'S ROLE IN ASIA

To an important degree Japan fears too close an association with the United States in the post-Sato world. The Japanese fear being linked to the American war effort in Vietnam, which it is felt, could taint Japan's future role as the re-builder of Asia. The Japanese already suffer from a somewhat tarnished image in Asia. Resentment and envy has come from Japan's ruthless investment practices, from the attitudes and practices of Japanese businessmen abroad, from its unfair trading methods, from its often smug or superior attitude towards other Asian trading nations, from its refusals to liberalize controls on imports of foreign capital and goods, and most of all, from its very success in economics. 1

Equally important to Japan is its lingering image from the Second World War. The animosity that Japan had built in this earlier period lingers on not only in Asia but also in Europe and throughout the world. Even in Okinawa (a part of Japan itself prior to and during the ${ }^{1}$ Far Eastern Economic Review, April 8, 1972, p. 21. 
war), animosity and fear exist. Only one week before reversion another atrocity had been reported by the Okinawan media in which Japanese military forces had apparently killed Okinawan civilians in the closing stages of the war. Other world-wide events, such as the Lod Airport suicide attack in Israel by Japanese extremists in May of $1972,{ }^{2}$ resulting in 26 deaths, have served to keep memories of the extreme devotion once held by the Japanese to old causes, still alive.

In addition to certain other signs of independence recently displayed, Japan has moved to assume part of the "leadership" void in "free" Asia, left by the American withdrawal. An example of this came on February 17, 1972, when the Japanese government offered Tokyo as a site for a possible summit meeting between the Pakistani President, Zulfikar Ali Butto, and the Bangladish Prime Minister, Shekh Mujikur Rahman. In late February of 1972, in another example of "leadership initiative" and its drawing away from dependency on the United States, Japan signed with France an agreement calling for joint nuclear research and development.

2 Following the Lod Airport terrorist attack in Israel, Japanese businessmen and tourists had to be evacuated from Puerto Rico to the U.S. mainland. Officials feared retaliation for the 14 Puerto Ricans killed at the Lod Airport by the three Japanese terrorists. See The Japan Times, June 1, 1972. 
The search by Japan for new sources of fuel comes , with an increased reluctance to continued dependence on the Middle East as a major source of oil. In their search, the Japanese have concentrated on possible sources close to home. Recently, Japan financed a ten million dollar loan to Burma in an oil-drilling venture that has produced exploration off the Burma coast in the Tenasserim area east of Ranqoon. There has even been talk in Japan of a trans-Andean pipeline which presumably would bring oil to the West Coast of South America for shipment by freighter to Japan. ${ }^{3}$ However, it is in Indonesia, as Asia's only major oil producer, ${ }^{4}$ that Japan places its real hopes. On May 14, 1972, Japan and Indonesia jointly announced that the former country will provide a loan of some $\$ 218$ million to help finance oil development projects. In return, Japan was promised a steady supply of low-sulphur Indonesian oil through the next

p. 5. The New York Times, April 9, 1972, section III. Indonesta, Malaysia and singapore suggested they might declare the Malacca Straits joint inland waters (in order to control pollution and navagational hazards). The Soviet Union, the United States and Great Britain all joined Japan in protest. The only great power to oppose the suggestion was China. The action on the part of Indonesia, Malaysia and Singapore, in addition to other factors, may also be linked to a regional awareness to the growth of Japanese influence in the area. See The New York Times, March 13, 1972, p. 9. 
ten years. Moreover, an important discovery of fuel by Japan outside of the Soviet Union would greatly reduce the effectiveness of the Russian inducement in the Siberian project.

Japan is currently also investing in other underdeveloped regionalareas. Once new agricultural sources have been located and secured, Japan will have eliminated another important area of dependency on the United States, which in the past, supplied a high proportion of these necessary agricultural goods to Japan. The Japanese expect such countries as Australia, Cambodia, Indonesia, and Thailand to be able to provide these goods more cheaply than does the U.S. ${ }^{5}$ The United States has in the past been the largest provider to Japan of such items, with an annual sales of over $\$ 1,000$ million. In terms of major future Japanese investment, concentration will be in both China and South Korea for general agricultural items, Taiwan particularly for sugar, bananas, pineapples and tea, North Vietnam for corn, animals and feeds, South Vietnam for general investments, and Thailand, where the Japanese investment already doubles that of the U.S.

5 The Japan Times, June 7, 1972, p. 10. 
In 1970, the greatest amount of world-wide aid from Japan went to South Korea, the Philippines, Indonesia, Hongkong, and Taiwan, in that order. ${ }^{6}$ Each of these three countries accounted for over 40 percent of Japan's total world-wide outflow of aid. In mid1971, Japan was in the process of increasing aid to Indonesia, Hongkong, and South Korea. ${ }^{7}$ The lack of increase in assistance to Taiwan and the Philippines can be explained, in the case of the former, by an improvement in relations with China, and in the case of the Philippines, by a general worsening of relations.

Japan has been one of the most unpopular countries to attend the recent United Nations Conference on Trade and Development (INCTAD), which began in mid-April of 1972. At the conference, the poorer nations attempted to gain some adjustment of economic policies from the rich nations. China was partially successful in assuming leadership of the poorer nations, which included many from Asia. Although Japan supplied the world's second highest amount of total aid for 1971 ( $\$ 1800$ million), or 0.93 percent of Japan's Gross National Product and well abcve the 0.76 percent average, 8 Tokyo was

${ }^{6}$ Far Eastern Economic Review, April 15, 1972, p.'48. 7 Ibid.

${ }^{8}$ The Japan Times, May 14, 1972, p. 3. 
criticized for its use of commercial credits rather than grants and concessional loans. Moreover, government loans from Japan have in the past been offered at 3.6 percent, a relatively high rate, with the world average at only 2.7 percent. ${ }^{9}$ The underdeveloped nations have also criticized Japan's "economic aggression," since government aid rose by a mere 5 percent in export credits and capital investment, while private aid rose by 44 percent. 10

In 1972, relations between Japan and the Philippines, much like recent Japan-U.S. relations, was at its lowest point since the Second World War. President Ferdinand Marcos of the Philippines and the Ambassador of Japan, Toshio Urabe, recently conferred over the growing anti-Japanese feeling among Filipinos. Following the conference, many Filipinos criticized Marcos for buckling under pressure. The critics charged that Japan had threatened to withdraw all financial assistance from the Philippines if anti-Japanese feelings continued. ${ }^{11}$ Much like the rest of Asia, Japan is the object of distrust and fear among many Filipinos. This

${ }^{9}$ Far East Economic Review, April 15, 1972, p. 48. ${ }^{10}$ Ibid.

${ }^{1 l_{\text {The Japan }}}$ Times, April 4, 1972, p. 1. 
negative reaction against Japan explains much of the recent rise in pro-American feelings. An example of the new orientation in Filipino attitudes is seen in the rapid growth of a Filipino organization claiming five million members, desiring to make the Philippines America's 51 st state. ${ }^{12}$

In contrast, Japan-Korean relations seem currently more solid. It is doubtful that in the near future Tokyo would to any degree shift its support from Seoul to Pyongyang. Several factors support this conclusion: (1) Japan has since 1965 recognized Seoul as the "sole legitimate government of Korea"; (2) tight financial relations exist between Tokyo and Seoul; (3) South Korea has a strong lobby with Japan's political leadership; and, (4) South Korea has not been left exposed from the Nixon trip to China to the same degree as has Taiwan. Although trade between Japan and North Korea continued to grow, doubling in value in 1971 and 1972, it fell far behind Japanese-South Korean trade. In 1971, trade with North Korea was valued at $\$ 60$ million, 13 while Japanese trade with South Korea was about $\$ 1,000$ million.

12 Ibid., May 14, 1972, p. 3. 13 Far East Economic Review, February 12, 1972, p. 33. 
Relations between the "two" Vietnams is considered secondary to that of Japanese-Korean relations. On February 11, 1972, Japan dispatched two diplomats to Hanoi in the first government mission to that country. One result from the effort was to increase trade between the two countries, which in 1971, totaled at a value of only $\$ 17$ million (but showed a strong increase of 30.8 percent). ${ }^{14}$ Japan's position in South Vietnam, as mentioned above, is a careful one, hoping for future investments but much contented with great economic gains already achieved. Japan looks hopefully forward to an expected role of providing great economic rehabilitation in both North and South Vietnam following the war.

Until the reversion of Okinawa, Japan had territorial claims against all of the Great Powers except the European Community. Following reversion, the problem of Okinawa changed from acquisition to administration, i.e., reversion changed only the nature of the problem in U.S.-Okinawa (Japan) relations.

Territorial claims between China and Japan are complicated by the inclusion of Taiwan as a part of the issue. The outstanding territorial problem between the three nations arose when oil deposits were discovered in 14 The Japan Times, April 8, 1972, p. 9. 
November of 1970 off the China coast in the Senkaku (Tiao-yu) Island group. Claims to the Senkaku Islands have also been made by South Korea. The islands are uninhabited and had had little real value until the oil discovery. International law is unclear on the subject and only urges the parties to meet and discuss the problem. Although American companies have often in the past joined with their Japanese counterparts to hunt for and develop oil discoveries, 15 the U.S. government, not wishing to get involved in the argument, has warned several American oil companies not to become involved in explorations in the disputed region.

The Senkaku Islands are situated at about the same distance from the northeastern tip of Taiwan as from the southern part of the Ryukyu Island chain (Japanese controlled since May 15, 1972). The islands, however, are about twice that distance from China proper and about four times that distance from the major Japanese island of Kyushu. Since Japan claims the Senkakus are included as part of the Ryukyu Islands reverted by the United States on May 15, 1972, the Japanese had hoped for a stronger American statement in their favor. The American position has been, however, that the problem ${ }^{15}$ For example, see Japan Report, Vol. XVII, No. 17, September 1, 1971, p. 8. 
should be settled by the countries concerned. Although the Japanese government has threatened to take a hard line (for example, by the strengthening of naval patrols in the vicinity), it is likely that an eventual compromise will be reached by all concerned. An example in moderation was made by the Japan Times, which advised that although there:

is absolutely no question about the territorial status of the Senkaku Islands... since it is the oil that has brought forth the fallacious claims to Taipei and Peking, we should not close our ears-- aside from the territorial issue-- to the possibilities of carrying out a joint international exploration of the seabed resources in the area around Japan's Senkaku Islands. 16

The People's Republic of China, like Japan, imports oil from the Middle East. Also, as in the case of Japan. the Chinese need for oil in the near future is projected to expand greatly. Regarding the inclusion of the Senkaku Islands as part of the Okinawa reversion, the Chinese position has been that the United States which occupied,

Japan's Okinawa after World War II, should return Okinawa to Japan completely and unconditionally. But it has no right at all to include China's territory Taioyu Island and other islands under its illegal occupation in the 'area of reversion.' 17

16 The Japan Times, March 10, 1972, p. 14 .

${ }^{17}$ peking Review, January 7, 1972, p. 14. 
In July of 1970, the Chinese charged that a Ryuku coastal patrol ship had sailed to the Senkaku Islands and "illegally set up markers there indicating they belong to the Ryuku group.": By also including the islands in Japan's "air defense'jdentification zone," Japanese "militarism is once again trying to occupy and annex China's territory by armed force." 18

One of China's first actions following its acceptance into the United Nations was to accuse Japan of plundering China's coastal resources. On March 3, 1972, Japan was accused in the General Assembly's Committee on Peaceful Uses of the Seabed and Ocean Floor of combining with the United States and Taiwan to plunder China's coastal seaded. An Chin-yuan, the delegate from China, declared that:

The United States is to this date forcibly occupying China's territory in Taiwan Province and of late it has colluded with the Japanese reactionaries and used the fraud of the reversion of Okinawa in an attempt to conclude into Japan's territory the Taioyu (Senkaku) and other islands pertaining to China's Taiwan Province.

The conflict over the Senkaku Islands includes not only Japan and the People's Republic of China. The Nationalist govermment of Taiwan also claims the

18 Ibid.

19 The Japan Times, Warch 5, 1972, p. 1. 
territories for "China." As in the case of Japan, Taiwan has tried to influence the United States into taking a stand in its favor on the islands issue, and like Japan, has failed. On April 10 and 11, 1971, Chinese and Chinese-Americans went into the streets of Washington, D. C., and other American cities in support of both Taiwan's and China's claims to the islands (in direct opposition to Japanese claims). 20 on May 23 rd, a full page advertisement appeared appealing to President Nixon and the members of Congress urging the American government to: (1) disavow any claims that the senkaku Islands as ever being any part of the American administered Ryukyu Islands; (2) recognize Chinese sovereignty over the islands; and, (3) censure actions by the Japanese government which "violates" Chinese sovereignty. 21

The problem of the Senkaku Islands has been complicated by the larger' and more important question in Japanese politics of the status of Taiwan itself, especially since the Nixon visit to China. The Japanese, following the Nixon "China-shock," feared a new American policy of rapprochement with China, leaving Japan behind and isolated. The Nationalist government of Chiang Kai-shek

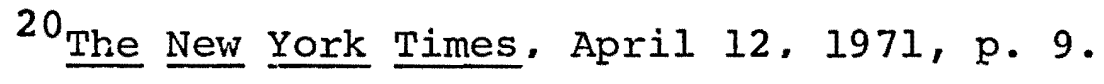
${ }^{21}$ Ibid., May 23, 1971. p. 30. 
on Taiwan has long been the Far Eastern symbol of the Cold war. While the 84-year old Chiang has ruled the Republic of China for over a quarter of a century, Japanese foreign policy can no longer afford to await the pleasure of his retirement atd a possible change in policy. Taiwan is the most important problem to be solved prior to any normalization in Japan-China relations.

The United States is not the only major power to have altered its policies towards China and against Taiwan. For example, Great Britain on March 13, 1972, decided to remove its official representation from Taipei and to enter into full-scale relations with Peking. At the same time, the British acknowledge "the position of the Chinese government that Taiwan is a province of the People's Republic of China." 22

How important is Taiwan to Japan's economy? Taiwan has generally sold to Japan agricultural products in return for processed raw materials, machinery, and iron and steel. Lately, the increased industrialization in Taiwan has commensurably increased Taiwanese exports of new goods (e.g., light industry items), to Japanese markets. Total trade with Taiwan was $\$ 1.034$ million in

22 The Japan Times, March 17, 1972, p. 16. 
1971, exceeding China-Japan trade. It was also reported that more Japanese tourists were going in 1971 to Taiwan than any other country in the world. In 1971, the total number of Japanese tourists going to Taiwan was 255,000 , up 44.1 percent from the 1970 total. At the same time, the total number of American tourists going to Taiwan in 1971 dropped by 8.5 percent from 1970.23

There is some disagreement over the amount of Japanese investment in Taiwan. Some "conservative" estimates put Japan's investment levels for 1971 at about $\$ 100$ million. 24 For the single year 1971, Japanese investment dropped from the 1970 level of 51 investment cases with a total value of $\$ 28.5$ million, to only 18 cases of investment projects totaled in value at $\$ 12.4$ million. 25 Nevertheless, Japan in 1971 still provided the world's largest amount of technological aid to Taiwan (79 out of 102 total cases of technological cooperation contracts). ${ }^{26}$ The significance of these

\footnotetext{
23 Far Eastern Economic Review, March 4, 1971, p. 67. 24 Ibid. 25 The Japan Times Weekly, March 18, 1972, p. 9. 26 The Japan Times, May 22, 1972, p. 12.
} 
figures is that while Japanese trade and investment in Taiwan for 1971 displayed a downswing reflecting the change in Japan's attitudes on the "Taiwan question," the total effect was not as drastic as some had previously suggested might occur.

On October 8, 1971, Peking spelled out a modified set of conditions in any normalization of relations with Japan. 27 The text of conditions was enumerated in a joint communique signed the previous day in Peking with a group of visiting legislators from Japan. The joint communique agreed that relations should be established between Japan and China "at the earliest possible date," and on the basis that Japan drop its relations with the Nationalist government on Taiwan including the abrogation of the peace treaty. Officially, the Peking government is still at war with Tokyo, having never signed a peace treaty following the conclusion of hostilities. The joint communique showed a moderating Chinese position, since they did not mention the question of war reparations, possibly amounting to billions of dollars. Neither did they mention the question of the Japanese-American defense treaty.

$$
3 .
$$

${ }^{27}$ The New York Times, October 4, 1971, pp. 1 and. 
In the following month of November, in an interview with Moto Goto, the managing editor of Asahi Shimbun (one of Japan's major newspapers), Premier Chou En-lai of China reiterated the basic and primary importance of setting the Taiwan question prior to Japan-China normalization. ${ }^{28}$ The Chinese Premier told the Japanese newspaper editor that:

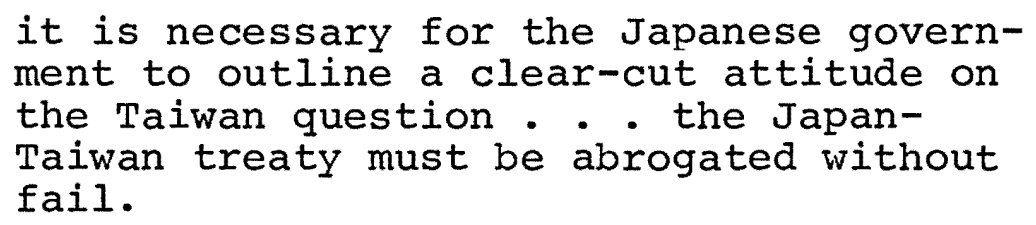

The Japanese Socialist Party, the Komeito party, and the Democratic Socialist Party, on the following day, submitted a resolution that would give recognition to China on Peking's terms. ${ }^{29}$ The Japanese Communist Party gave only "reluctant support" to the measure.

Specifically, Peking's demands for normalization are all related to Taiwan and are based on China's "three principles": first, to recognize the government of the People's Republic of China as the only legal government of China; second, to declare that Taiwanese self-determination or independence movements are unacceptable; and third, to declare the peace treaty of

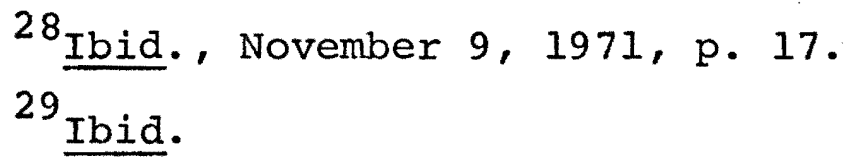


1951 between Japan and Taiwan invalid.

One of the most disturbing statements by a leader

of Japan ever made public to China since the 1951 peace treaty with Taiwan was made by Prime Minister Sato in November of 1969. After having"met with President Nixon, Sato declared that the "security in the Taiwan area to be a most important factor in the security of Japan." 30 The reaction to Sato's speech in the Chinese press was instantaneous. For example. the newspapers Jen-min Jihpao, Hung-ch'i and Chieh-fang-chun Pao pointed out in their editorial:

It has long been our consistent policy to develop diplomatic relations with all countries on the basis of the five principals of peaceful co-existence. but on no account can we tolerate the invasion and occupatior of our sacred territory by any imperialism or social-imperialism. We are determined to liberate Taiwan. U.S. imperialism and Japan militarism had better consider this paragraph more carefully 1

In another example, the Chinese media claimed that at the Sato-Nixon meeting in November of 1969, the two leaders had decided to go,

${ }^{30}$ For the complete text see The New York Times, November 22,1969, p. 14.

31"U.S. Newsman on Japanese Militarists' Territorial Designs on Taiwan," Survey of China Mainland Press, No. 4592 (from Hong Kong Press, Ta Kung Pao, on February 2, 1970), Hongkong: U.S. Consulate General, February 5, 1970, p. 128 . 
so far as to include China's sacred territory Taiwan province within Japan's sphere of incluence, flagrantly clamouring that they would prevent the chinese people from liberating Taiwan. At the same time, Eisaku Sato also sent his brother Nobusuka Kishi, a first-class war criminal, to Taiwan for conspiratorial activities. All of these facts have further exposed the rabid ambitions of the Japanese reactionsaries to reoccupy China's sacred territory Taiwan. 32

Two years later, in 1972, the official Chinese

position had not changed:

Sato reaffirmed time and time again after his talks with Nixon that the 'U.S.-Japan security system is needed,' that 'the system will be persisted in,' and that

it can be stated explicitly that Taiwan is not excluded from the area $\rho^{f}$ the U.S.Japan security treaty system. 33

Where Chinese attitudes had altered concerned the recent thawing in Soviet-Japanese relations, awakening the worst in China's fears. Peking accused Japan of conspiring with the Soviets on the anti-China issue, and even being instigated by the Russians to occupy by force "China's sacred territory," Taiwan. 34

To a great extent, the Chinese were able to use the Nixon "China-shock" to their advantage and against

32 Ibid. , "Reactionary Japanese Government Rabidly Opposes China in Collusion with U.S. Imperialism," (New China News Agency-English, Peking, December 27, 1969), No. 4569, January 5, 1970 .

33 Peking Review, No. 4, January 28,1972, p. 21.

${ }^{34}$ Ibid., No. 6 , February 11,1972, p. 19. 
the Japanese. During the Nixon visit, the Chinese toughened their recent language against the exposed Japanese, including that concerning the Taiwan question:

The Japanese militarists have become more frenzied since the latter part of 1971 in their sinister manoeuvers to annex China's Taiwan Province. They have whipped up public opinion and recruited followers for creating an 'independent Taiwan' and even chosen the main actors for the performance. Nearly all these dirty moves are directly or indirectly connected with Japanese Prime Minister Sato, Foreign Minister Fukuda and arch war criminal Kishi... The Japanese reactionaries . . . are attempting to create an 'independent Taiwan' through a bunch of Chinese traitors in their pay, so as to reduce Taiwan to a Japanese colony again. Such a tactic is indeed identical with the devilish stratagem of Japanese imperialists in rigging up 'Manchukuo' more than 40 years ago! Sato and his ilk $\cdot 35^{\circ}$ are worthy disciples of Tojo... 35

In response to the attacks from China, from the Opposition parties, and from many groups and organizations in Japan, Prime Minister Sato on March 1, 1972, modified his previous position saying that now he fully recognized Peking's territorial claims over Taiwan. This statement represented a major shift within "Sato's paradox." While forces were building in Japan for normalization of relations with China, the pre-conditions

${ }^{35}$ Ibid., Nos. 7-8, February 25, 1972, pp. 27-28. 
set by Peking meant nothing less than a complete Japanese sell-out of Taiwan. The Nixpon "China-shock" gave Sato the pretext of doing what he could never had dared before; move in bold directions towards a China accommodation and away from the tatterea "ties with Taiwan, an issue that was splitting the internal political cohesion within Japan and within the Liberal Democratic Party. In 1971, Sato had admitted that it was:

not an overstatement to say that Japan relations with China form the core of Japanese diplomacy, but he could offer no formula whereby Japan could improve relations with Peking while maintaining relations with Taiwan. 36

Unfortunately for Sato, his respite had come too late, his political support at home long since having dissipated in strength. In addition, China refused to deal with Sato or his Government, preferring to wait until his successor (Tanaka) had been named. The Nixon "China-shock" had inadvertently helped Mr. Sato out of his paradox over the Taiwan commitment, but somewhat ironically it had also had helped him out of office.

36 The New York Times, January 1, 1971, p. 1. 


\section{CHAPTER VII}

\section{SINO-JAPANESE RELATIONS}

Several of the most important problems between Japan and China in '1972 were: (1) the Japan-U.S. Security Treaty; (2) the growth of Japanese militarism; (3) Japan's relations with Taiwan and South Korea; (4) the economic expansion of Japan, particularly in Asia; and, (5) the fear in China of any economic, political or military understanding between Japan and the Soviet Union.

To some degree, China and Japan share the same Confucian culture and common racial characteristics.

But in many ways Japan has had more in common with Europe than with China. Perhaps this dissimilarity is more obvious to the Asian eye than to the European. 1

Nevertheless, China's relations with Japan have, since the early $1960^{\prime}$ 's, been better than with either of the other two Așian Great Powers. In 1957, Chou En-lai had said that the Chinese did not object to Japan's relations with the United States, but "what they did not approve of was their one-sidedness and Japan's refusal to develop

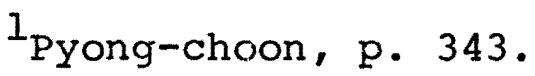


friendly relations with China." ${ }^{2}$ By 1958, the Chinese government had:

adopted an attitude of uncompromising opposition to the Japanese government and encouraged a mass struggle against it. The reasons for this shift may be sought in the Chinese calculations about the impossibility of developing relations with Japan without a prior expulsion of American influence, their hopes about the possibilities of realizing this objective, and their faith in their capacity to impress Japan with China's new power. ${ }^{3}$

During the mid-1960's, China's image and influence in Japan suffered, primarily from Peking's own behavior. With the main exception of the extreme left-wing organizations, Japanese public opinion was adversly affected by such factors as China's development of nuclear weapons, its wars of liberation, its real or supposed role with the Communist Party in Indonesia, and the results from the excesses of the Cultural Revolution. JapanChina relations were also negatively affected with the coming to power of Sato.

Yet in the following four years Peking's concern with the more immediate problems of the Indochina war, border clashes with the Soviet Union, and the Cultural Revolution tended to push Japan into the background of its foreign policy considerations.

2

Dutt, p. 233.

3 Ibid., p. 234 
When the Chinese did discuss Japan it was usually in terms of American or Soviet 'collaboration.' 4

In addition, the:

major Soviet diplomatic and economic offensive throughout Southeast Asia and Moscow's call for an Asian collective security pact were both interpreted in Peking as an elaborate policy of containment dependent on a Moscow-Tokyo axis. 5

What China specifically fears is that Japan may decide to meet what Prime Minister Sato has called, Japan's "international obligations." In an article for the Chinese newspaper Jen-min Jih-pao in January of 1970, Peking outlined its fears of Japanese power-emergence. 6

The Sato administration has always followed U.S. imperialism, colluded with the Soviet revisionists and reactionaries of all countries, remained hostile toward China, and opposed to the national democratic revolutionary movements of the peoples of all Asian countries. The Sato administration continues to 'uphold' the Japan-U.S. 'Security Pact,' or the JapanU.S. military alliance, which points its spearhead against socialist China and the countries in Asia, steps up Japan-U.S. military collusion under the camouflage of the 'return of Okinawa,' and further ties Japan on the chariot of aggression

\section{4}

Saywell, p. 513.

5

Ibid.

${ }^{6}$ "Refutation of Sato's Clamor for So-called

'Fulfiliment of International Obligations, " Survey of China Mainland Press, No. 4596 (Peking Jen-min Jin-pao, January 30,1970$)$, Hongkong: U.S. Consulate General, February 13, 1970, pp. 122-123. 
of U.S. imperialism. In response to

Nixon's so-called 'New Asian Policy' the Sato administration actively serves as the military police in Asia in a futile attempt to round up the reactionaries of all countries to establish a clique of military aggression backed by the United States and using Japan as the 'backbone' to act inimically against the people of China and other Asian countries. This is the 'international obligations' which the Japanese reactionaries want to 'fulfill'!

Waving the banner of 'sovereignty and defense,' Japanese reactionaries energetically expand armament and prepare for war, clamoring to engage in 'localized' wars of aggression by using the 'Self-Defense Force (Note: i.e., the Japanese Army, Navy and Air Force) as the principal force' with the support of U.S. imperialism. They also cl.amored about sending their fleet to 'defend' the strait of Malacca and establish their power at sea. These are the 'international obligations' which Japanese reactionaries want to 'fulfill':

Japanese reactionaries included Chinese territory, Taiwan Province, Korea, Indo-china, etc.. into Japan's sphere of 'defense' and clamored to use force to hinder the Chinese people in their liberation of their own territory of Taiwan Province and to engage in aggressive adventures against Korea and other areas. These are the 'international obligations' which the Japanese reactionaries want to 'fulfill'!

Waving the banner of 'cooperation' and 'aid for development' the Japanese reactionaries engage in economic expansion and infiltration against countries in Southeast Asia, rob them of their resources, ruin the local national industries, control their economy, and strive to include these countries into Japan's sphere of colonization so as to renew their dream of 'Greater East Asian Sphere of Co-prosperity.' These are the 'international obligations' which the Japanese reactionaries want to 'fulfill'! 
Memory is still fresh in the minds of the people in Asia and the Pacific area about the Japanese militarists' launching of the war of aggression and their crimes of slaughtering and robbing the people of Asia. They are highly vigilant against the aggressive designs of the Japanese reactionaries. Acts of aggressive expansion by the Japanese reactionaries in Asia and the Pacific area can only arouse strong resistance and counterattack from the people in Asia and the Pacific area which will make the Japanese reactionaries encircled by the people of all countries.

Great leader Chairman Mao pointed out: 'Imperialist wolves must remember, the era when they were free to change the fate of mankind and rape the countries in Asia and Africa has gone forever and will never return.'

Japan is the only Asian nation which can clearly

offer both economic and military superiority to China's self-image as the leader of Asia.

As a status-quo power bent on internal development and the enhancement of regional stability through the maintenance of non-communist neighbors, Tokyo presents a long-term obstacle to Peking's regional influence ambitions. Chinese foreign-policy-makers seem particularly sensitive to Japan's efforts at regional leadership through such organizations as the Asia-Pacific Council. (ASPAC) arid its hosting of a number of regional conferences beginning in 1966 . . .

Japan's military alliance with the United States has

long been a sore point with China. This is basically

${ }^{7} \mathrm{~s}$. W. Simon, "Some Aspects of China's Asian Policy in the Cultural Revolution and its Aftermath," Pacific Affairs (Spring 1971), p. 30 . 
been because the alliance is seen by China as merely a device for Japan to further its resumption of rearmament. Now however, the situation may have reversed itself, with the Security Treaty offering to China perhaps the only viable alternative to complete Japanese rearmament. Today, China faces a new problem of imponderable importance: the growing threat of cooperation between Japan and the Soviet Union, far more dangerous to China than any Japanese-American alliance.

If. Japan does decide to rearm completely, there is very little china can do to prevent it. The alternatives of the People's Republic of China to,

offset Soviet and American influence in Japan is very limited, consisting primarily of trade blandishments and appeals to segments of the Japanese Communist and Socialist Parties, neither of which has much foreign policy leverage. 8

Chinese internal and external propaganda has always distinquished between the rulers of Japan and the Japanese people. An often quoted statement, made originally in January of 1964 by Chairman Mao, demonstrates this:

Japan is a great nation. It will certainly not allow U.S. imperialism to ride roughshod over it for long. The last few years have seen the constant broadening of the patriotic united front of all strata the Japanese people against U.S. imperialist

Ibid., p. 31 . 
aggression, oppression and control. This is the surest guarantee of victory in their patriotic struggle against. U.S. imperialism. The Chinese people are convinced that the Japanese people will be able to drive the U.S. imperialists from their soil and realize their aspirations for indegpendence, democracy, peace, and neutrality.

More recently, in the case of Taiwan's status, Peking's "people to people offensive" has stated that:

The Chinese people will never allow any outside interference in this matter. This just stand of the Chinese people has enjoyed wide and resolute support from the Japanese people. The Japanese people demand for the restoration of diplomatic relations between Japan and China and the development of Japan-China friendship is like a mighty torrent surging ahead irresistibly. Sato's deliberate design to antagonize the Chinese people and carry out the 'twoChinas' plot and his ambition to commit aggression on China's territory Taiwan are doomed to fail. 10

Although less recently since the Nixon visit,

China has had in the past, the advantage of appealing as a utopia to alienated 'students and intellectuals. ${ }^{11}$ For example, Peking claimed that after 1965, "a new leap took place and a new situation appeared," as groups of

9 "Japanese People's Just Patriotic Struggle Against U.S. Imperialism Rolls on," Survey of China Mainland Press, No. 4590 (Peking, January 27, 1970), Hongkong: U.S. Consulate General, February 3, 1970, p. 58 .

\section{0} Peking Review, March 10, 1972, no. 10, p. 17. 11 Hinton, p. 234 . 
workers and students were organized to fight in the struggle. In many places of Japan, since "the autumn of 1967, the courageous and revolutionary Japanese people . . have engaged in a series of fierce struggles with the repressive reactionaries and armed police." 12 In 1972, the extreme character of such organizations and their violence had alienated most Japanese of any sympathy .

The general policy of China had been to roll out the red carpet for almost any visiting Japanese who opposed Sato, in or out of government. Inter-party Communist relations between China and Japan retained, in 1972, the hostile character established earlier in the decade. The leaders of China had recognized earlier that they would have to work,

not through the JCP but through the Socialist Party which was the dominant opposition in the country and through their trade union organization sOHYO. Peking's task was facilitated by the fact that both these organizations were uncompromisingly against the military alliance with the United States and the retention of U.S. bases on Japanese soil and were emotionally pro-Chinese. 13

Four recent developments have heightened Chinese 12 op. cit., p. 57. 13 Dutt, p. 239. 
consternation over Japan's role in Asia: (1) the Sato-Johnson 1967 talks on Asian security: (2) the Nixon Guam doctrine of mid-1969, increasing Japan's role in Asia; (3) the November 1969 Sato-Nixon talks, in which Taiwan's and South Korea's independence was linked to Japan; and (4) the June 1970 Japan-U.S. Security Treaty. At a time when economic intercourse is rapidly expanding between the two countries, China remains jealous and in fear of Japanese diplomatic and commercial successes in Southeast Asia, Taiwan, and quite possibly, Siberia. In addition, while Japan fears China's nuclear weapons, the Chinese worry continuously over the possible remilitarization of Japan. Moreover, following the disasters of the "united front" (conducted on official levels), the Peking Government has since aligned itself with the revolutionary masses of various Asian countries. Japan was seen in China as only an Asian image of American imperialism. 14

Another problem of Japan-China relations has been the growing nationalism in both countries, which may in the future hamper efforts to reach a solution

$$
{ }^{14} \text { LaFeber, p. } 144 .
$$


of the important questions. ${ }^{15}$ Largely, security in Asia will depend upon the future course of Japanese domestic politics and upon the ability of the ruling governments to keep excessive nationalistic feelings under "control." Quite possibly,

the very considerable cultural and racial affinity between China and Japan may one day provide a basis for removing today's conflicts. This would, of course, be contingent upon Japan's recognition of China's claims to be the senior partner, and the chances in the present decade of such a Sino-Japanese rapprochement are very small

China's strength as both a conventional and nuclear power has been a factor of Asian politics for some time. The People's Republic of China's,
capability projected into the 1970's seems formidable; a limited number of kiloton and megaton weapons relative to the U.S. and the U.S.S.R., and a limited delivery capa- bility, yet one which could reach to other parts of mainland Asia, Asiatic U.S.S.R., Japan and the Ryukyus, Taiwan and the Philippines. 17

Yet, the critical question is of "intent," and the desire to initiate aggression on the part of the regime in China has yet to be proven a fact. The conventional

15 ioachim Glaubitz, "Moscow-Peking-Tokyo: A Triangle of Great Power Relations," Institute for the Study of the U.S.S.R. Bulletin (June 1971), p. 33 .

16 Ibid., p. 32 .

17 J. H. Buck, "Japan's Defense Options for the 1970 's," Asian Survey (October 1970), p. 894. 
strength of the Chinese military against any other Great Power is found in its defensive depth; less in any offensive projection. This has at least been the general attitude of the Japanese and they seem little worried, having developed a policy of "wait and see."18 Trade pressure, next to the political parties, may be China's most powerful influence within Japan. Although the Chinese position has basically always been that economic intercourse and political relations could never be separated, throughout the 1960's and into the 1970's, Japan has been able to hold economic intercourse with China without solving the difficult political and ideological questions. During a speech to the Diet in March of 1967, Prime Minister Sato said that his policy vis-a-vis China would be to "separate politics from economics."19 In fact, however, this had been the policy of Japan since the early 1950's.

Generally, the attitude of the average Japanese businessman has been swayed by economic rather than political considerations. In addition, because, of the large memberships and diverse compositions of these associations, they are

${ }^{18}$ Storry, p. 333. ${ }^{19}$ The Japan Times, March 15, 1967, p. 1. 
not unanimous concerning the China issue. But the general attitude of these business groups is to promote trade with Communist China, but not officially to recognize it. 20

The Chinese, on the other hand, "are so completely swayed by political feelings that they have allowed their distrust of Japan to enter into their consideration of commercial matters." 21 For example, in 1962 , after having realized the growing economic power and independence of Japan, Peking dropped its earlier conditions and again gave its consent to renew private trade between the two countries. 22

In 1968, China for the first time insisted on political statements being included within the annual trade agreements. It was from the Cultural Revolution that the Chinese trade negotiators adopted a rigid and doctrinaire attitude in trade dealings with Japan. The general decline which Japanese-Chinese trade experienced in that year was brought about since the Japanese were unwilling to purchase China's exportable items (rice. iron ores, tobacco and livestock). What Japan wanted,

$$
\begin{aligned}
& 20_{\text {Jan, }} \text { p. } 611 . \\
& 21_{\text {Lee, }} \text { p. } 137 . \\
& 22_{\text {Dutt, p. }} 254 .
\end{aligned}
$$


but China could not export, was such materials as coal and corn. In addition, at the time Japan was following a rigid economic policy. Because of the regulations in the use of Export-Import Bank funds, China was unable to borrow from Japan, turning to Western Europe instead.

In April of 1970, China took a major step in its continuing attempts to influence Japan's trade policies. Premier Chou En-lai declared the future would see China refusing to have any dealings with foreign firms who thereafter dealt with or invested in Taiwan or South Korea. delivered weapons to South Vietnam, or were partners with U.S. firms. "The alacrity with which the majority of Japanese firms complied with the Chinese demands were surprising," and Peking "has at its disposal an instrument with which to exert political pressure upon Japan and influence her economic relations with her neighbors." 23

Upon returning from Peking in November of 1971, a delegation of ranking Japanese businessmen reported that trade between the two countries would grow, but only gradually. The influential character of the group's

${ }^{23}$ Glaubitz, p. 28 . 
composition was a reflection of the qrowing importance of the China trade to Japan's economy.

Yoshizane Iwasa, president of the Fuji Bank, a member of the mission, said in an interview that within the next two or three years it would be difficult to achieve a radically fast increase in trade between China and Japan. However, he forecast a 'gradual increase year by year.' Mr. Iwasa said that the Chinese had explained that they wanted to develop their industry with their own initiative. They want to stand on their own feet. . .24

In February of 1972, the Japanese Government came to a major policy alteration. It was decided then to approve future applications for Export-Import Bank credits to China. The Government had previously refused to permit use of the bank's funds for trade with China because of a private promise to this effect made by the late former Prime Minister Shigeru Yoshida in a letter to the Taipei Government in 1964.

Continued liberalization of trade policy seems to be a part of Japan's future attitude with China.

The scope for economic cooperation appears boundless. Japan has much to offer in helping to develop the Chinese heavy, petrochemical, synthetic fibre, and eletric power industries which are high on China's economic plan. 25

24 The New York Times, November 28,1971, p. 1. ${ }^{25}$ Far Eastern Economic Review, March 4, 1972, p. 45. 
In 1971, total trade between China and Japan increased 9.4 percent over 1970. Of this, Chinese exports of raw silk doubled to become the top export item to Japan. China's biqgest imports are iron and steel materials, chemicals, machines, and raw materials for textile manufacturing .

Trade between China and Japan is probably more important to the former, since Japan has been accumulating a trade surplus, and with the exception of raw silk and soy beans, none of the principal items imported from China are in any real demand. In fact, Japan must find new items from China to import.

To boost exports to Japan, China needs to follow international trade practices in respect to pricing, quality control, designing and shipping. Richly endowed with natural resources, it could meet many of the needs of the humming Japanese manufacturing industries if its products were competitive-- if it really made the decision to export them. 26

If this decision were made, Japan could help to industrialize China, while the latter, in turn, could supply badly needed natural resources.

It has, however, been the very success of Japan's economy that has added to the problems of Japan-China 26 Ibid. 
relations. One such aspect is:

Peking's fear that Japan is becoming a paramount and anti-Chinese power in Southeast Asia. Japan is Indonesia's number one trading partner; she dominates Thailand's transportation, textile, and iron and steel industries; and is a leading economic power in such key areas as Malaya, Burma, and even Australia. The Japanese realize that if any military is flashed in support of this economic expansion, it will arouse memories of the hated Japanese occupation and Co-Prosperity sphere in Southeast Asia. The Chinese constantly play on such memories, but so far without much effect. 27

The "Okinawanization of Japan" is seen as part of a new phase in Japanese imperialism, edging closer to outright militarism. Peking sees the reversion of Okinawa as part of the American policy of letting Asians fight Asians.

Through the Okinawan 'reversion' fraud, the United States and Japan hope to tone down the struggle of the Asian people, the Japanese people in particular against the U.S.-Japanese reactionaries. 28

To neutralize the actual or imagined military threat from Japan, China, as one possibility, would unofficially like to see a four-power nonaggression pact with the Soviet Union, the United States, and Japan. ${ }^{29}$ In

27 LaFeber, pp. 146 and 178.

28 peking Review, January 28, 1972, No. 4, pp. 20-21. ${ }^{29}$ Far Eastern Economic Review, March 4, 1972, p. 28. 
addition to with the fear of a remilitarized Japan, also exists a fear of a Japan-Soviet alliance. Given the choice, China would unquestionably prefer the U.S.Japan Security Treaty to any Moscow-Tokyo alliance. It is with the Soviet Union that China now competes in attracting Japan, following the growing Japanese disparity with the U.S. If the proposed Siberian project serves as the greatest soviet enticement, it is the northern territories issue that acts as the qreatest hinderance. China continues to play to the latter theme, irritating the Russians, while supporting the demands of Japan. One sympathizer of the Soviet Union concluded that the,

Chinese leaders are blackmailing Japan's ruling circles with the possibly anti-Japanese trend of the newly-emerging Chinese-U.S. rapprochement. They domonstrate to the Japanese ruling circles their blatant antiSovietism and solidarity on the 'Northern territories' issue. the solidarity on which Japan may allegedly rely in bringing pressure to bear on the Soviet Union. 30

${ }^{30} \mathrm{D}$. Yostokov, "The Foreign Policy of the People's Republic of China Since the Ninth Congress of the Communist Party of China," International Affairs (January 1972), p. 31 . 
CHAPTER VIII

\section{JAPAN-SOVIET RELATIONS}

Throughout the post-war period and until the Nixon visit to China, Russo-Japanese relations had generally been poor. Since the China-U.S. "detente," relations between the Soviet Union and Japan have improved. The improvement in relations with Japan has come about from what can be termed a Russian "goodwilloffensive." At a time when American-Japanese relations are at their weakest point in the post-war era, SovietJapanese relations are at their strongest.

The Soviet Union had been a leader among those Asian nations who did not favor the revitalization of Japan following the conclusion of the second World War. A formal peace treaty between the two countries has never been concluded. Instead, a joint Russo-Japanese "peace declaration" was signed on October 19, 1956. Agreed to in the declaration was a technical end to the state of war. The signing of the document also provided for: the opening of diplomatic and consular relations between the two countries, Japan was to receive Soviet support for United Nations membership, Moscow was to repatriate Japanese nationals, and both countries were 
to drop certain respective claims against the other. Moreover, it was agreed that.Japan and the Soviet Union would begin talks for future trade agreements, fisheries conventions, and hopefully, a formal treaty of peace. While some of these expectations were eventually realized $(e . g .$, in a trade agreement signed in 1963 and extending through 1966, an estimated exchange of some $\$ 700,000,000$ worth of goods were called for); as of mid-1972, a formal peace treaty had not yet been signed. $^{1}$ As in the case of China, strong economic ties between Japan and the Soviet Union have not led directly to equally strong political ties.

Part of the recent Russian policy in Asia has consisted of the Erezhnev Collective Security Plan. At a time when the shift in emphasis of Soviet foreign policy has meant a relaxation of relations with Europe and the United States in the West, the critical problem of the Sino-Soviet conflict, remains. After having originally expressed his collective security plan at the International Communist Party Conference in June of 1969, Brezhnev, in a speech in March of 1971, again expressed interest amid a "massive media campaign directed at

$1_{\text {Negotiations designed to arrive at a formal }}$ peace treaty are expected to begin in late 1972 . 
building closer Soviet-Japanese relations." ${ }^{2}$ Moreover, after a period of apparent oblivion, the:

resurgence of this theme in the soviet media cancides with the reactivation of Moscow's Asian policy. Diplomatic efforts toward closer relations are foreseen. But no spectacular breakthroughs in that direction should be expected until presently prevailing circumstances in the area undergo serious changes. 3

In April of 1971, at the 24th Congress of the Communist Party of the Soviet Union, General Secretary Brezhnev re-enumerated his collective security plan. It called for the prohibition in the exercising of military power among Asian nations, the respect of national sovereignty and nonaggression against other nations' borders, the noninterference in other nations' domestic affairs, and, the promotion of cooperation in economic and other spheres based on equality and mutual benefit. Advantageously amplifying this spirit, Radio Moscow on May 16, 1972 (the day following reversion), called on Okinawa to be made free of nuclear weapons and to be completely demilitarized. ${ }^{4}$

2 The Japan Times Weekly, May 27, 1972, p. 4.

${ }^{3}$ Jean Riollot. "Moscow and Asian Collective Security," Radio Liberty Dispatch, October 14, 1971, p. 1 .

$$
4 \text { The Japan Times, May 17, 1972, p. } 1 .
$$


The American reaction to the Brezhnev Collective Security Plan, as publicly detailed by Assistant Secretary Marshall Green, was that a:

non-aligned Southeast Asia is a worthy long-term goal; but there are a lot of hurdles to get over before you get there, and I feel that all of the leaders of Southeast Asia, while recognizing that it would be desirable to work toward that long-term goal, understand these difficult problems that must be surmounted, that neutrality, to be real, must be based upon adequate defense and security. ${ }^{5}$

A number of factors are, however, pushing the Soviet Union to greater initiative. With the recent vigor in Sino-American relations,

Peking's reported flexibility on the question of the normalization of SinoJapanese relations, the current crisis in United States-Japanese economic relations, and the current mood of Japanese opinion are all factors that may further strengthen Moscow's conviction that diplomatic action in Asia in this stage should revolve around the Japanese issue. 6

Responding in March of 1972, Prime Minister Sato, at a plenary session of the House of Councellors, expressed interest in studying the Brezhnev plan for the collective security of Asia. ${ }^{7}$

5

Marshall Green, Assistant Secretary for East Asian and Pacific Affairs, "Interviewed on Meet the Press," Department of State Bulletin, Vol. LXVI, No. 1712, April 17, 1972, p. 575 .

6 Riollot, p. 3.

${ }^{7}$ See The Japan Times, March 2, 1972, p. 1. 
In part, the Soviet qoodwill-offensive aimed at Japan is defensive in nature. The Russians fear a change in Japanese attitudes following the Nixon visit to China. More specifically, they fear the American initiative towards China will stampede Japanese businessmen and politicians in calling for a complete normalization of Sino-Japanese relations.

It was with both positive and negative aspects of the problem in mind that Foreign Minister Gromyko journeyed to Tokyo in January of 1972. The visit by the Soviet Foreign Minister had important implications, both within and outside Japan and the Soviet Union. In China, for example, an improvement in Soviet-Japanese relations could only add fuel to the existing fears of Russian encirclement. Among the Gromyko discussions designed to stimulate better relations with Japan, it was "an open secret that China had figured prominently in the Soviet-Japanese talks." 8 In addition, Gronyko was reported to have warned the Japanese:

We wish you to have friendly relations in China . . But I think it should be done without impairing relations with the Soviet Union. 9

8 "A New Move in the Great Power Game," Newsweek, February 7, 1972, p. 29.

9

Ibid. 
The Soviet use of pressure and interference in. Japanese political matters had long been a major sore point in the relations between the two countries. For example, the,

Russians sent Deputy Prime Minister Mikoyan to Japan in 1961 on a goodwill mission. During his visit he remarked that Japan would be welladvised not to renew the security treaty with the United States. He was told in no uncertain terms that Japan would brook no interference in its internal affairs, and after his departure, Russia still ranked at the bottom of all nations in Japan's popularity poll.10

In a second example, the soviet government in March of 1970 notified Japan that Soviet fleet units would be holding firing practice off the northern coast of Japan. Although aimed at China principally and Japan only indirectly, the response from Japan was so critical that the Soviets agreed to cancal both operations. ${ }^{11}$ The Japanese, in turn, have even instigated their own counterpressures. For example, in March of 1971 the Soviet media complained that three Japanese fighter plans had buzzed a Soviet destroyer on maneuvers off southern Japan. ${ }^{12}$

10 Buss, p. 636 .

${ }^{11}$ Gibney, p. 108.

${ }^{12}$ See The New York Times, April 20, 1971, p. 5. 
Although today, Japan fears the Soviet Union probably more than any other, country in the world, the Japanese know that their suspicions are valid only if the Russians consider them an enemy. Today, both China and the Soviet Union compete against the other, hoping to win Japan as an ally. Not unexpectedly, the methods each uses to induce (or coerce) Japan, differs. The Russians currently hold two major enticements (for the purpose of bargaining with Japan): the northern islands issue: and the natural resources of Siberia. Given the choice, the Russians would choose to employ the latter as a bargaining issue. Among the two alternatives, the Siberia offer has for the Soviet Union the greatest potential rewards and the fewest dangers. Moscow, in attempting to entice Japan with the Siberian venture, would like from that country one billion dollars in credit as part of a mutual investment deal. These funds would be used to help build a proposed 4000-mile pipeline, expected to carry oil from West Siberia near Tyumen, to the Pacific port of Nahodka. This, the Russians explain, would then provide Japan with an annual flow of 50 million tons of highgrade oil. For the Russians, in addition to the other concessions won from the Japanese, the agreement would help to fulfill the ninth Soviet five-year economic 
plan, as well as to provide a ready supply of fuel to the eastern coast of Siberia, enhancing Soviet naval power in the Far East. 13

The major problems yet to be overcome by Japan are associated with the footing of the project itself (mostly at government expense). In addition, the Japanese must erase the,

doubt which persists over becoming too heavily dependent for such a vital source of energy as oil from a totalitarian government that could with a twist of the spigot turn off the supply. . . it is highly probable that the Russian determination and haste in the proceeding with this project are motivated at least in part by their controversy with Peking. Japan would surely be ill-advised to get caught in the middle of the SovietChinese squabble. 14

Thus far, Japan and the Soviet Union have been limited to concrete agreements in outlying areas only. These agreements include the calling forth of Japanese assistance for the development of several Soviet Far Eastern ports, an agreement in 1967 providing for an Arctic route along the northern coast of the soviet Union aiding transportation from Japan to Europe, and, an agreement that allows Japan Air Lines, as the only

${ }^{13}$ The Japan Times, February 26, 1972, p. 14 . 14 Ibid. 
non-Socialist air line, to make regular flights over Siberia to Moscow. 15

The Soviets first offered the Siberian venture to Japan in 1960. Twelve years later, Japan had still not made a formal move toward acceptance. One reason for the Japanese reluctance in consideration of the project is the implications such an agreement would have for the American-Japanese security aqreement, and also. on Japan-China relations. In regard to the latter, the Japanese investment at Tyumen, so close to the Chinese border, would mean a significant political investment on the Russian side of the Sino-Soviet conflict. The Nixon "shocks," however, have helped to push Japan and the Soviet Union slowly and cautiously closer towards reaching șome agreement on the siberian question. The Soviet ambassador to Japan, Oleg A. Troyanovsky, said in January of 1972, that the "Soviet Union does not need foreign help in the development of Siberia, but any country is welcomed to share in the exploitation of Siberian natural resources."16

Concerning the great potentials in Siberia, Pravda ran a series of articles in March of 1972,

${ }^{15}$ Glaubitz, p. 36 .

${ }^{16}$ The Japan Times Weekly, January 8,1972, p. 2. 
detailing the need for new equipment and for the new pipeline. 17 The article noted that when completed, the new pipeline will carry millions of tons of ob petroleum to the East. Perhaps as a warning to the cautious Japanese, the article noted that, since the ob area and Alaska pose a good many commion problems, "American firms are displaying great interest in what is being done along the Ob."18 Already, the daily extraction of oil has reached the level of 148,000 tons." The article concluded, pleading that the level "cannot go even one ton higher! Why? Because the existing pipelines are loaded to capacity."19 What is needed, of course, is money (yen).

Meetings between the two powers, which include discussions on the siberian project, continue. For example, from July 15 to July 27, 1971, a National Council of Governors from Japan visited a variety of industrial plants and state farms, including a discussion in Moscow "of the status and further development of

${ }^{17}$ Current Diqest of the Soviet Press, Vol. XXIV, No. 10, $\overline{\text { April 5 }}, \overline{1972}, \overline{\mathrm{pp}} . \overline{1-6}$. (See also Pravda, March 4, 5 and 9, 1972.)

${ }^{18}$ Ibid. , p. 1. ${ }^{19}$ Ibid. , p. 2. 
cultural and economic ties and coastal trade between

East Siberia and Far Eastern territories and provinces and Japanese prefectures. "20

From February 21 to February 24, 1972, a conference of the Soviet-Japanese and Japanese-Soviet Commissions for Business Cooperation met in Tokyo. The Soviets proposed at the conference that Japan offer a bank-tobank loan of at least one billion dollars, at an interest rate of 6 percent a year, for the construction of the trans-Siberian pipeline. The Russian newspaper, Izvestia, optimistically observed that this fifth conference,

opens a new page in the history of the development of economic relations between the two countries . . . there is complete confidence now that the present projects will be transformed into practical deeds, because the plans discussed at the Tokyo conference rest on sober-minded planning and on the objective necessary of peaceful coexistence between the U.S.S.R. and Japan and of mutually advantageous cooperation in the interests of the peoples of both countries. 21

Although, as yet, the fifth conference has produced no hard and fast agreements on the Siberian investment question, other joint projects were also

20 Ibid., Vol. XXIII, No. 30, August 24, 1971, p. 17. (See also Pravda, July 27, 1971, p. 2). ${ }^{21}$ Ibid., Vol. XXIV, No. 9, March 29, 1972, pp. 1516. (See also Izvestia, March 1, 1972, p. 2.) 
considered. For example, discussed were the mining of coal in South Yakut, the development of oil and gas resources on the continental Shelf of Sakhalin, the supply of pulp wood through the port of Wrangel, and the shipment of natural gas from Yakut."

The Siberian venture would, of course, be profitable to Japan for a number of reasons. The expected high quality of oil from Tyumen would reduce Japan's present major pollution problem; the sale of steel pipes and construction equipment would help Japanese businesses; other possible natural resources in Siberia might be opened to further development by the Japanese; and, with the opening of the Tyumen oil deposits, Japan would no longer be forced to depend on the Middle East.

Indicative of an important segment of opinion in Japan is Fumio Tanuka, president of the $0 j i$ Paper Company and negotiator with the Soviet Union for the pulp-exploitation in Siberia. Tanuka noted that "the Japanese economy can no longer depend solely on the U.S. as heretofore," and predicted "the need for Russian-Japanese collaboration based upon the development of Siberia will increase steadily in the years 
ahead."22 Trade between Japan and the Soviet Union has, in fact, shown steady growth.

Following the summer of 1966 and Soviet Foreign

Minister Gromyko's visit to Japan, both sides have since held regular consultations at the ministoral level. This has made Japan only the third nation with which Moscow has made such an agreement. 23

In 1969. trade between the Soviet Union and Japan totaled some $\$ 730$ million. In 1970, Japan replaced

Britain as Russia's top trading partner.

The same year saw Japanese trade with

Moscow reach an unprecedented $\$ 812$ million

-. This roughly equalled Japanese

trade with China-- though Moscow left a surplus export balance while Peking imported much more than it exported. 24

This, however, also clearly points to a major problem in Soviet trade with Japan, i.e., the Soviet Union (as in the case of the United States), imports more from Japan than it exports. At the same time, if Japan and the Soviet Union could reach an agreement on the Siberian investment question, the result of Japan importinq

22 The Japan Times Weekly, February 19, 1972, p. 4. ${ }^{23}$ Glaubitz, p. 27.

24 Far Eastern Economic Review, March 20, 1971,

pp. 27-28. In contrast, U.S. trade with the Soviet Union for the same year was only $\$ 177$ million. See The Japan Times, April 20, 1972, p. 17. 
resources from Russia, would go far in correcting the imbalance of trade between the two countries. In 1970, the major area where Soviet exports to Japan indicated a strong increase was in round timber (i.e., from $13,600,000$ in 1969 to $15,300,000$ in 1970).25

In an Izvestia article in January of 1972, Japan was offered a "better deal" from the Socialist world than the current one they were getting from "Nixon's America." Russian and Japanese trade "volume increased even during the past year, despite the fact that 1971 was one of the most difficult years for the Japanese economy in the entire postwar period." In December, a general agreement was signed on deliveries from the U.S.S.R. to Japan of industrial wood chips, and deciduous pulpwood logs, etc. The importance, outside the obvious, is that the Soviet Union is offering Japan a stable economic relationship that could replace in importance the one now shared between Japan and Nixon's America. 26

In this sense, the Soviet Union is not only attempting to keep Japan and China apart, but the Russians are also attempting to use the Nixon "shocks" as well as other means, to lure Japan away from the United States.

${ }^{25}$ Current Digest of the Soviet Press, Vol. XXIII, No. 28, August $10,1971, \mathrm{p} .3$.

$$
26
$$

Ibid., Vol. XXIV, No. 2, February 9, 1972, p. 16. (See also Izvestia, January $14,1972, \mathrm{p} .2$. ) 
The most important items the Soviet Union imports from Japan are: pulp and paper, machinery and equipment,

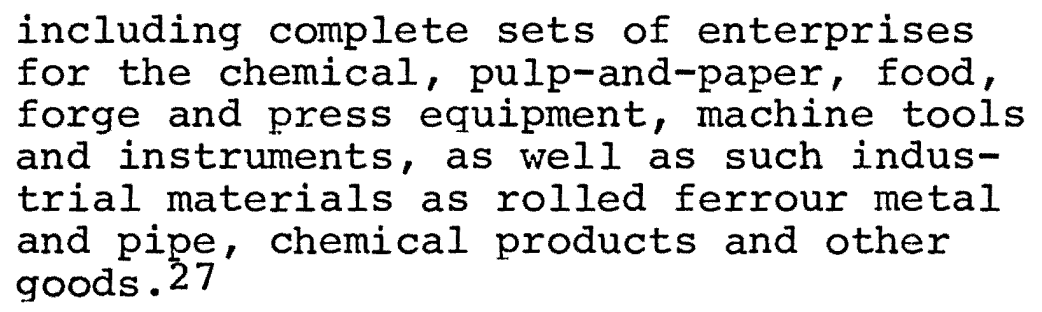

In the past several years, there has been a substantial growth in Soviet buying of Japanese consumer goods and raw materials. The most important Russian exports to Japan are currently various types of fuel, raw minerals, and industrial materials that include coal, petroleum and petroleum salts, asbestos, nickel, aluminum, pig iron, commercial timber, cotton and other goods. L'Lately, Soviet exports of machinery and equipment to Japan have risen. 28

A Pravda article in late 1971 expressed hope that Japan could develop the Far Eastern regions of the U.S.S.R. wherein enormous deposits of fuels, power and raw material wealth and industrial and agricultural

27 Ibid., Vol. XXIII, No. 42, November 16, 1971, p. 1. (See also Pravda, October 20, 1971, p. 5.) 28 Ibid. 
resources were concentrated. ${ }^{29}$ Japan could make good use of these materials, since 99 percent of their petroleum and 100 percent of their lumber is imported.

The movement in Japan business and public circles for the further "development of trade and economic ties with the soviet Union is explained by economic necessity and corresponds to Japan's national interests. . The first important steps have already been taken. 30

In 1968, the first general agreement had been concluded and "went beyond the framework of ordinary commercial transactions." 31

In 1970 , a second general agreement was concluded which declared the initiation of a cooperative effort between the two countries in designing a new seaport at Wrangej. Bay. The new seaport is expected to provide additional facilities in the handling of the growing volume of trade between the Soviet. Union and Japan. In addition, the agreement also called for the construction of two new fishing ports in the Far East: one in Troitsa Bay (Maritime Territory), and one in Kholmsk (Sakhalin Province). Moreover, a new fiveyear trade agreement (1971-1975) was signed between the

$$
\begin{aligned}
& 29 \text { Ibid. } \\
& { }^{30} \text { Ibid. } \\
& { }^{31} \text { Ibid. }
\end{aligned}
$$


two countries, envisaging a steady growth of exchange in goods.

During 1971, over 20,000 Japanese tourists visited the Soviet Union, while air travel over Siberia from Tokyo to Moscow developed at a fairly rapid pace. Large scale tourism, an Izvestia article claimed, "is an important new factor making for rapprochement between the peoples of the two countries." 32 Following the 1970 establishment of "fraternal ties"between the cities of Kiev and Kyoto, the number in 1971 was increased to nine. There was a sharp increase in the number of people studying Russian language in Japan. There has been, also, expanded cultural and scientific contact between the Soviet Union and Japan. The article concluded, hinting the "only thing required for the transformation of these possibilities into reality is to eliminate the obstacles in the way of full normalization .... ."33

Certain high-ranking elements within the Sato Government favored shifting the country's ties from the United States to the Soviet Union. For example, it was

32 Ibid., Vol. XXIV, No. 2, February 9, 1972. p. 17. (See also Izvestia, January 14, 1972, p. 2.).

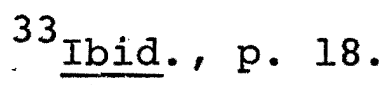


reported in September of 1971 in an interview with the newspaper Asahi, that Japanese Agriculture and Forestry Minister Agaki had come out in favor of improving relations with the Soviet Union, rather than "dancing to the U.S.A.'s tune..." 34 The means for the improvement in relations was to be found through the joint development of Siberia. By broaching "Japanese-American relations in that same interview, the Minister expressed dissatisfaction with Washington's latest measures, which are seriously damaging Japan's economic interests." 35

The most important problem with the Soviet Union at Japanese insistence, is the northern territories issue. Since the Soviet "capture" of Southern Sakhalin and the entire Kurlie Island chain in 1945, every Government of Japan has insisted that the entire territory is not Russian. The refusal of Moscow to comply in some form with the Japanese complaints has been a source of irritation between the two countries. The reversion of Okinawa by the United States on May 15, 1972, has only exposed and irritated the problem further.

Until the Nixon-China "shock," the Russians had ${ }^{34}$ Ibid., Vol. XXIII, No. 35, September 28, 19.71, p. 19 . ${ }^{35}$ Ibid. 
even refused to discuss the problem with Japan. In April of 1970, with Soviet President Podgorny scheruled shortly to visit Japan,

Kawashima Shohiro, Vice President of the ruling Liberal Democratic Party, went to Moscow, intending to hold unofficial talks on the Northern Islands with Premier Aleksei Kosygin. The Soviets, however, rebuffed this Japanese initiative. Due to illness, President Podgorny's visit was cancelled, and Kosygin was unable to receive Kawashima. 36

What the Japanese have lacked in success on the northern territories issue they have made up on determination. While the Sato Government had asked for the four southernmost islands only, the Japanese Communist Party and the Japanese Socialist Party had requested the return of the entire Kuriles chain.

The JCP's maxi demand, of course, is prompted by its continuing feud with the Soviet leadership over the interference in the Japanese party's internal affairs, as well as the knowledge that the territorial issue is supported by $a$ broad segment of the Japanese people. 37

The Japanese have made the return of the islands a precondition for the signing of a peace treaty; while the Russians fear that a territorial concession with Japan might lead other countries, such as Rumania and China,

$36_{\text {Weinstein, p. } 198 .}$ p. 12. ${ }^{37}$ Far Eastern Economic Review, December 4, 1971, 
to clamor for similar consideration.

The real problem centers not on the two nearest and smallest islands, Habomai and Shikotan, which the Soviets have made known for some time could be the subject of serious discussion. The problem is rather the two largest islands of Kunashin and Etorofu, on which the Soviet position has been unyielding. The Japanese,

on their side, have committed themselves to a firm official stand in their demand for their return. Maps in Japan nowadays do not show the national boundary as separating Hokkaido from Kunashiri but put the dotted line between Etorofu and the Kurlie Island immediately to the north of it... The recovery of these northern islands, then, must be regarded as a basic, if long-term aim of Japanese foreign policy: an option, in other words, that a Japanese Government is not likely to forego. 38

Today almost no Japanese live in the northern territories since most were evacuated in 1945 to the mainland prior to Russian occupation. The chief victims of the territorial problem has been the Japanese fishermen of eastern Hokkaido. It is they who, from 1946 through 1970, have had 1336 fishing boats seized, 11,316 crew members captured, ${ }^{39} 22$ boats sunk, and 32 lives

${ }^{38}$ Storry, pp. 331-332.

${ }^{39}$ With the Soviet goodwill-offensive highlighted by the visit of Foreign Minister Andrei Gromyko to Japan in January of 1972, 14 Japanese fishermen in a good-will gesture were released from Soviet custody. 
lost from hostile soviet actions. ${ }^{40}$

Another major problem associated with the return of the northern territories is that, should the islands become Japanese territory, such an action would, in a sense, "open the door" to the sea of okhotsk, now almost considered a "Russian lake."' The loss by Russia to the Japanese would be strategic, and would allow greater claim by Japan against the Russian-attempted conservation of the fishing resources in the once-rich Okhotsk shoal. Reports from the Russian press have indicated the importance attached to this area and the resentment of even present Japanese activities. The "commercial value of the Sakhalin-Hokkaido shoal was almost destroyed . . because the Japanese commercial fisheries persisted in taking undersized herring from the already depleted shoal." 41 Now, the "last remaining herring reserve, the Okhotsk shoal, is directly threatened as a result of the stand the Japanese have taken." 42 For this reason, among others, the Russians have taken a strong stand on the northern islands issue. An ${ }^{40}$ The New York Times, January 12, 1971, p. 2. ${ }^{41}$ Current Digest of the Soviet Press, Vol. XXIII, No. 15, May 11, 1971, p. 39 .

\section{Ibid.}


article in Izvestia, in January of 1971, detailed the motivated strength of the Soviet stand, arguing the Japanese "revanchist motto of 'struggle for the islands," are rooted:

in the general trend of 'balancing economic potential and military power, ' which has become the 'idee-fixe' of Japan's militaryindustrial complex . . in attempting to whip up a militarist and revanchist frenzy in their country, the leaders of the Liberal Democratic Party are clearly losing their sense of reality. . . it is an unquestionable fact that the actions of certain Japanese circles in attempting to revise the result of the Second World War are creating a serious obstacle (to peace.). ${ }^{43}$

The above article was accompanied by another, five days later, in Pravda. Japan, the article complained, was making "brazen territorial claims," and developments:

have shown that the heightened militarization of Japan directly threatens the people of Asia and the Japanese people themselves . . It would be advisable for the soldiers of fortune in the Far East to take a look at the calendar and assure themselves that they are no longer living in the 1930's...44

In September, Pravda, in another among numerous articles, laid even greater stress on the territorial issue by dropping of the nuclear bomb on Hiroshima.

43 Ibid., Vol. XXIII, No. 4, February 23, 1971, p. 20. (Also, see Izvestia, January 26,1971, p. 2.)

44 Ibid., Vol. XXIII, No. 5, March 2, 1971, pp. 2829. (See also Pravda, January 31, 1971, pp. 1 and 4.) 
The article asked, why?

Was it simply the length of time that had passed since the bombing? No, the cause lies not only in the time that has passed but also in the policies of certain circles that are striving to make people forget Hiroshima . . The Japanese revengeseekers try to 'justify' their claims to a part of Soviet territory mainly on two counts: that what they call Japan's 'northern territories' had always belonged to her, and that their future had allegedly not been finally decided by international agreements, including those signed by Japan. 45

To answer these claims, Pravda continued: "facts and documents" concerning the issue of the ownership of the Kurile Islands,

incontrovertibly testify that long before the first Japanese made their appearance on the Kuriles, the islands had already been discovered, explored and settled by the Russians, and had become a part of the territory of Russia by right of discovery. - The point is that the men in Tokyo have 'forgotten' the unconditional surrender, the wartime and postwar agreements, which laid down how and what Japan would have to pay for her policy of militarism and aquression, which had inflicted so many calamities on the peoples of Asia. ${ }^{46}$

While the Russian argument is correct, it is

neither totally nor geographically germane to the issue. In 1875, the southern half of Sakhalin was ceeded to

${ }^{45}$ S. Budkevich and M. Raginsky. "The Tokyo Trial: A Reminder," International Affairs (August 1971), pp. 76-77.

46

Ibid. 
Russia in exchange for the Kuriles (in the Treaty of St. Petersburg). Following the conclusion of the Russo-Japan War in 1905 (and the Treaty of Portsmouth), Japan kept the Kuriles Islands while taking back the southern part of Sakhalin. However, the Kurile Islands that Japan had won and held from 1875 to 1945 did not include the four southern islands that the Japanese and Russians dispute today. The two southernmost and smallest islands (Habomai and Shikotan), were, until 1945, Japanese through exploration and settlement from the early days. The Russians have for some time shown interest in returning these two islands. The Soviets, however, have refused to discuss the return of the two larger islands, Kunashiri and Etorofu. Both of these islands have also been Japanese since the early days, and were confirmed to Japan by the Treaty of Shimoda in 1855 .

Although Japan's claim to each of the four islands may seem equally valid, the Russians have contended that.

it is the Japanese side that has for many years frustrated the conclusion of a peace treaty with the U.S.S.R., seeking to substitute a discussion of the long settled 'territorial issue' for talks about a peace treaty. The Japanese government has made no secret of the fact that it does not want a real peace treaty, but a 'peace treaty on the basis of a return of the northern 
territories.' This stand of the Japanese ruling circles clashes sharply with the urge of the peoples for a relaxation of international tension and does nothing at all to promote the normalization of relations with the Soviet Union. 47

The six-day visit by Foreiqn Minister Gromyko to Japan in January of 1972 was an indication of a moderating position on the Russians side. As part of the goodwill-offensive, Gromyko's visit was designed to probe Japan's intentionsfollowing the problems raised by the U.S.-China rapprochement. At the same time that Gromyko was attempting to take advantage of recent JapanAmerican conflicts, China was using the northern territories issue to its own advantage. According to a report in Asahi Shinbun (a leading Japanese newspaper), Chinese Premier Chou En-lai told a visiting Japanese delegation that "the reversion of the northern territories has not yet been decided, but we support the return demands of the Japanese people." 48

The major impact thus far from the soviet qoodwill-offensive was felt in late January of 1972. Following a series of talks by Sato and Gromyko, it was agreed that the two countries would study conditions prerequisite

47 Ibid. , pp. 70 and 107. 48 The New York Times, January 24,1972, p. 9. 
to the conclusion of a Japanese-Soviet peace treaty, "which informed sources said included the northern territorial problem."49 Elimination of the northern territories as an issue would eliminate the major problem currently standing in the way to complete normalization of relations.

The impetus upon the Soviet Union from the U.S.China "detente" and the shifts of attitudes in Japan, have brought about a sudden improvement in RussoJapanese relations unexceeded in the post-war period. The 1972 Gromyko visit to Japan also produced additional agreements; Foreign Minister Gromyko and Prime Minister Sato agreed to an exchange of visits by the Soviet and Japane Prime Ministers; Gromyko and Foreign Minister Fukuda approved a cultural agreement and made plans to negotiate a scientific and technological pact; a further expansion of the already growing and important trade relations would be explored; the fourteen Japanese fishermen then being held by Soviet authorities would be released; and most important, of course, was the pledge to begin talks within the year designed to produce a signing of a formal peace treaty ending world War II. 50

49 The Japan Times Weekly, January 29,1972, p. 1. 50 The Japan Times, January 28, 1972, p. 12. 
The latter statement indicated an improvement in the possibilities of solving the northern islands issue, and indicated flexibility on the part of both sides to compromise. Moreover, the Soviets no longer demand a complete Japanese abrogation of defense ties with the United States as a pre-condition to peace talks. This new Russian attitude is indicative of the deterioration, in their opinion, of the significance of the U.S.-Japan Security Treaty. In February of 1972, with the conclusion of the Gromyko visit, Prime Minister Sato was forced in the Diet to defend his foreign policy; declaring he would not renounce the Japan-U.S. Security Treaty in return for a peace treaty with the Soviet Union. Sato was rebutting the argument advanced by the chairman of the Japan Socialist Party. The latter wanted the Government, to negotiate a return of all the Kurile Islands to Japan with the Soviet Union in return for the abrogation of the Japan-U.S. treaty. 51

However, the signing of the peace treaty with the Soviet Union will not end all the current problems existing between the two countries. The bad feelings that exist are due not only from Russian actions late in

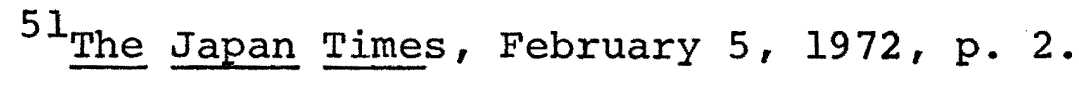


the Second World War, but also are due from the bad feelings that have evolved in Russia from Japan's foreign policy in the last few years. More specifically, Soviet commentators have recently attacked the Japanese role in Vietnam for their production of war materials, in allowing the use of Japan's ports for the servicing and refueling of United States' warships, and in the diplomatic support given Washington by the Japanese Government of Sato. In addition, Moscow has chastised the past Japanese Government for the support given American "intrigues" against the Democratic People's Republic of Korea, as well as the signing by Japan of the treaty which normalized relations with the Republic of Korea. In fact, at one time,

Soviet propagandists had gone so far as to postulate collaboration between Tokyo and Bonn toward reviving the World War II alignment. The visit by the Chancellor Kurt Kiesinger to Tokyo in May of 1969 provided a field day for the Soviet press . . .52

One Soviet observer, writing in Pravda, saw the question of Soviet-Japan relations for the future is essentially a "political struggle," flaring:

${ }^{52}$ Marian P. Kirsch, "Soviet Security Objectives in Asia," International Organization, Vol. XXIV, No. 3 (Summer 1970), p. 459. 
over the path that Japan will be traversing in the years to come. Hill Japan continue to follow a course of military cooperation with the U.S.A., fraught with the constant threat of being pulled into the adventures of U.S. imperialism, or will Japan free itself from the fetters of its military alliance with the Pentagon and settle firmly on a course of peaceful development and cooperation with all countries and peoples. $5 \overline{3}$

In other words, will Japan in the years to come continue to follow a course of association with the United States, or will Japan in the future come to depend more heavily on the Soviet Union, China, or even exclusively on Japan itself? This is a question that to a great extent will be eventually answered by the after-effects of the Nixon "shocks."

\section{CONCLUSION}

The period from 1969 to 1972 was critical for the development of Japan's foreign policy. In that period, Japan evolved from a role as an indistinct shadow, mimicking the American image in foreign policy, to the role of a quasi-independent Asian Great Power. After 20 years as the junior American partner in Asia, Japan had been jolted by a series of Nixon "shocks."

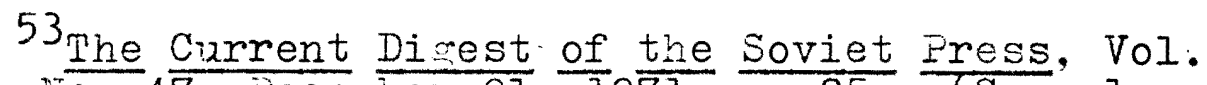

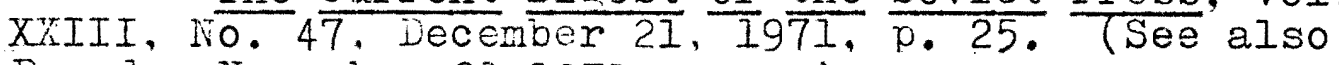
Pravda, November 23,1971..p. 5.) 
Although U.S.-Japanese relations had been deteiorating prior to 1972, the Nixon "shocks" went far in providing the stimulus necessary for improving Sino-Japanese and Soviet-Japanese relations. At a time when the ties between American and Japan are at their weakest point in the post-var period, both China and the Soviet Union compete for the security that an alliance with Japan would provide. To a very great degree, the future course of Japan's foreign policy will save a tremendous impact on the balance of power in Asia. The Government of Prime Ninister Tanaka is aware that any reduction of confidence with the United States in the security treaty must mean an increased dependence on some other Great Power, i.e., China or the Soviet Union; or on Japan itself.

A question of primary importance to all of the nations in Asia concerms the degree to which Japan might in the future rearm. The tremendous growtin of Japan's post-war economy allows for and necessitates increased political, and even perhaps, military responsibilities. In general, it can be expected that Japan will remilitarize at a proportional extent to which confidence has been lost in the reliability of the. 
American security alliance.

Finally, to a large degree, while the Soviet Union and China compete to draw Japan, at this propitious moment, further away from its American ally, the United States finds itself also with a delicate task in Japan: to revivify and solidify those remaining ties of goodwill that exist between American and its "most important ally in Asia." 


\section{A S E I E C T E D}

B I B I I O G R A P H Y

\section{BOOKS}

Barnett, Doak A. China After Mao. New Jersey: Princeton University Press, 1967.

Buss, Claude Albert. Asia in the Modern World; a History of China, Japan, South and Southeast Asia. New York: The Macmillan Company, 1964.

Cole, Allan B.: Totten, George 0.; and Uyehara, Cecil

H. Socialist Parties in Postwar Japan. New

Haven: Yale University Press, 1966.

Dutt, Vidya Prakash. China's Foreign Policy, 1958-

1962. New York: Asia Publishing House, 1964.

Greene, Fred. U.S. Policy and the Security of Asia.

New York: McGraw-Hill Book Company, 1968.

Hellmann, Donald C. Japanese Foreign Policy and

Domestic Politics: The Peace Amreement with the Soviet Union.

Hinton, Herold C. China's Turbulent Quest. New York: The Nacmillan Company, 1970. Hsin-hai, Chang. America and China: A New Approach 
to Asia. New York: Simon and Schuster, 1965.

Kahn, Herman. The Emerging Japanese Superstate: Challenge and Response. Englewood Cliffs: Prentice-Hall, 1970.

Kajima, Morinosuke. Modern Japan's Foreign Policy. Rutland Vermont: Charles E. Tuttle Company, 1969.

Kawai, Kazuo. Japan's American Interlude. Chicago: The University of Chicago Press, 1960.

Morris, I.I. Nationalism and the Right Wing in Japan: A Study of Post-war Trends. Iondon: Oxford University Press, 1960.

Warth, Kobert D. Soviet Russia in World Politics. New York: Twayne Publishers Inc., 1963. 


\section{ARTICLES}

Brzezinski, Zbigniew. "Japan's Global Engagement." Foreign Affairs, (January, 1972), pp. 270-283. Buck, J.H. "Japan's Defense Options for the 1970's." Asian Survey, (October, 1970), pp. 890-899. Budevich, S., and Raginsky, ir. "The Tokyo Trial: A Reminder." International Affairs, (August, 1971), pp. 72-78.

Bull, Hedley. "Ihe New Balance of Power in Asia and the Pacific." Foreign Affairs, (July, 1971), pp. 669-682.

"China's New Diplomacy: A Symposium I." Problems of Communism, XX, (November-December, 1971), pp. $1-84$.

"China's New Diplomacy: A Symposium II." Problems of Communism, XXI, (January-February, 1972), pp. I81 .

Curtis, G.I. "The 1969 General Election in Japan." Asian Survey, (October, 1970), pp. 859-871. Farnsworth,I.W. "Japan: The Year of the Shock." Asian Survey, (January, 1972), pp. 46-55. Gibney, Frank. "The View from JEpan." Foreign 
Affairs, (October, 1971), pp. 97-112.

Glaubitz, Joachin. "Moscow-Peking-Tokyo: A Triangle

of Great Power Relations." Institute for the

Study of the USSR Bulletin, (June, 1971), pp.

$20-33$.

Hitchcock, D.I. "Joint Development in Siberia: Decision Making in Japanese-Soviet Relations."

Asian Survey, (Narch, 1971), pp. 279-300.

Hirawawa, K. "Japan's Future World Role and Japan-

ese-American Relations." Orbis, (Spring, 1971),

pp. 338-350.

Hutching, R. "Soviet Defense Spending and Soviet

External Relations." International Affairs,

(July, 1971), pp. 518-531.

Jan, G.P. "The Japanese People and Japan's Policy

Toward Communist China." Western Political

Quarterly, (September, 1969), pp. 605-621.

Jan, G.P. "Party Politics and Japan's Policy Toward

Communist China." Orbis, (Winter, 1971), pp. 973-997.

Kahn, Herman and Singer, Max. "Japan and Pacific

Asia." Asian Survey, (April, 1971), pp. 399412 .

Kirsch, M.P. "Soviet Security Objectives in Asia." Intermational Organizations, (Summer, 1970), 
pp. $451-478$.

Kitamura, H. "Japan's Economic Growth and its International Implications." World Today, (May, 1971), pp. 195-202.

Krasilnikov, A. "Japan and the Developing Countries." International Affairs, (February, 1971), pp. $41-45$.

Ia Feber, Walter. "China and Japan: Different Beds, Different Dreams." Current History, (September 1970), pp. 142-147.

Langdon, F.C. "Japanese Liberal Democratic Factional Discord on China Policy." Pacific Affairs, (Fall, 1968), pp. 403-415.

Iee, Chae-Jin. "The Politics of Sino-Japanese Trade Relations. 1963-1968." Pacific Affairs, (Summer, 1969), pp. 129-144.

Melby, John F. "Great Power Rivalry in East Asia." International Journal, (Summer, 1971), pp. 457468 .

Mendel, D. H. "Japan's Security in the 1970's: A Symposium." Asian Survey, (December, 1970), pp. 1031-1069.

Onishi, A. "Japanese Interests in Southeast Asia: . A Japanese View." Asian Survey, (April, 1971), pp. $413-421$. 
Pyong-choon, Hahm. "Korea and the Emerging Asian

Power Balance." Foreign Affairs, (January, 1972), pp. 339-350.

Ray, H. "Soviet Diplomacy in Asia." Problems of Cormunism, IXX, (1iarch-April, 1970), pp. 4649 .

Phee, T.C. "Japan: Security and Militarism." World Today, (September, 1971), pp. 390-400.

Saeki, Kiichi. "Toward Japanese Cooperation in

Siberian Development." Problems of Communism, XXI, (May-June, 1972), pp. I-II.

Saywell. Willam. "Japan's Role in the Pacific and

China's Response." International Journal, (Surnmer, 1971), pp. 506-522.

Sergienko, I. "Japanese Militarism Raises Its Head." International Affairs, (June, 1969), pp. 2934 .

Simon, S.W. "Some Aspects of China's Asian Policy in the Cultural Revolution and its Aftermath." Pacific Affairs, (Spring, 1971), pp. 18-38. Stockwin, J.A.A. "Foreign Policy Perspectives of the Japanese Left: Confrontation or Consensus?" Pacific Affairs, (October, 1971), pp. 435-445. 
Storry, R. "Options for Japan in the 1970's.".

World Today, (August, 1970), pp. 325-333.

Taira, Koji. "Japan's Economic Relations with Asia."

Current History, (April, 1971), pp. 225-230.

Wakaizumi, Kei. "Japan and Southeast Asia in the

1970's." Current History, (April, 1971), pp. $200-206$.

Weinstein, Martin E. "Japan and the Continental

Giants." Current History, (April, 1971), pp.

193-199 and 241-242.

Yostokov, D. "The Foreign Policy of the People's

Republic of China Since the Ninth Congress of

the Communist Party of China." International

Affairs, (January, 1972), pp. 29-41. 


\section{PERIODICALS AND NEWSPAPERS}

The Current Digest of the Soviet Press.

The Department of State Bulletin.

Economist.

Far Eastern Economic Review.

The Harold International Tribune.

Japan Report.

The Japan Times.

The Japan Times Weekly.

Newsweek.

The New York Times.

Peking Review.

Radio Liberty Dispatch.

Survey of the China Hainland Press. 